
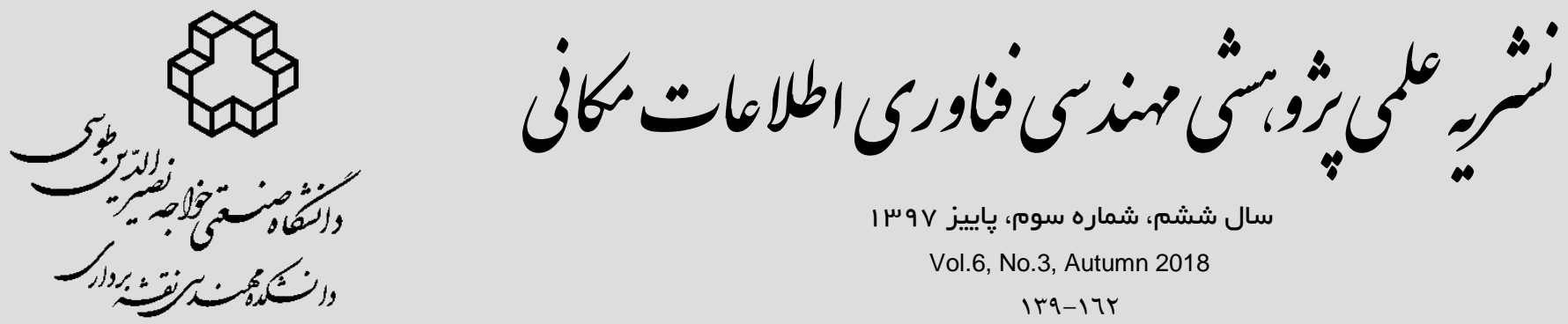

I سال ششم، شماره سوم،، ياييز

Vol.6, No.3, Autumn 2018

$1 r 9-17 r$

توسعه و ارزيابى تخمين تابش موج كو تاه فرودى در سطح بر اساس عمق ايتيكى هواويز SARA

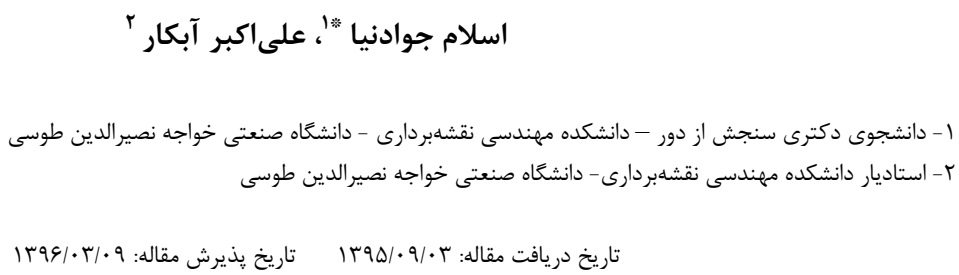

جكيده

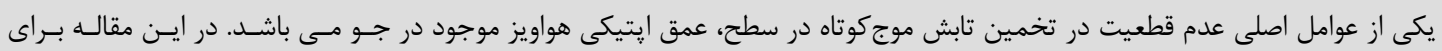

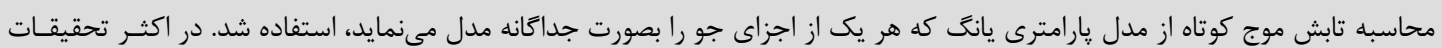

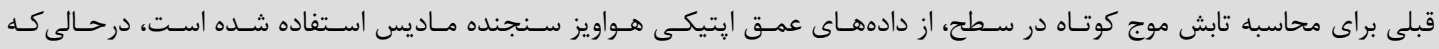

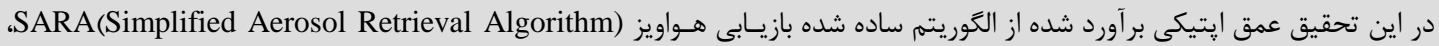

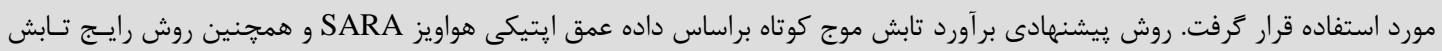

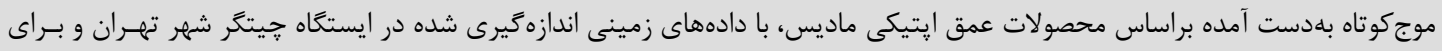

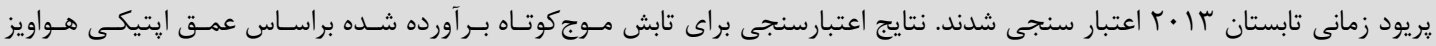
SARA

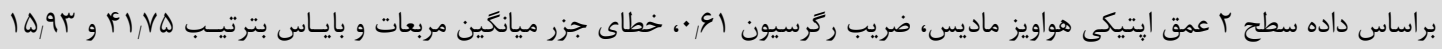

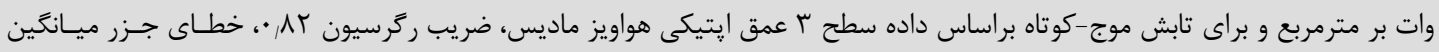

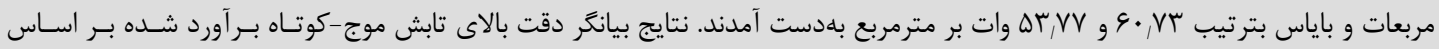

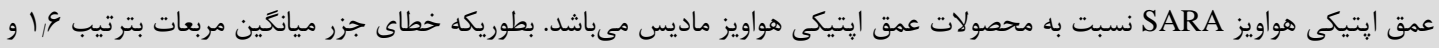

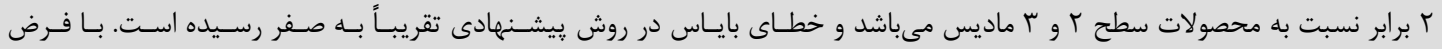

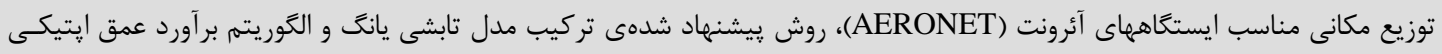

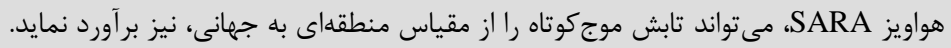
كليدوازهها: تابش فرودى موج كوتاه در سطح، عمق إتيكى هواويز، ماديس

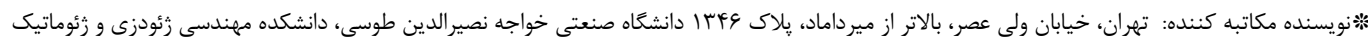

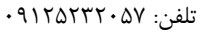


مخصوصاً مـاديس مسىتوانـــد مناسـبتــر باشــند، زيـرا

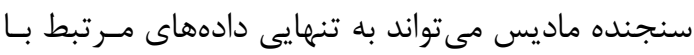

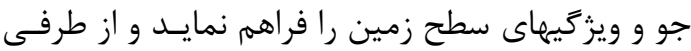

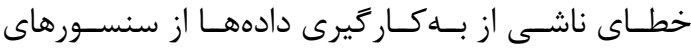

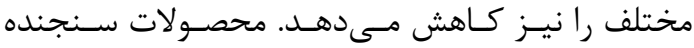

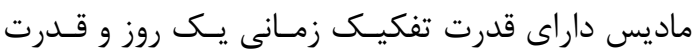
تفكيك مكانى هاى مختلف از قبيل • له متر، • • له متر

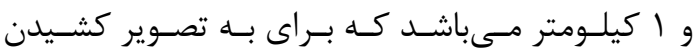

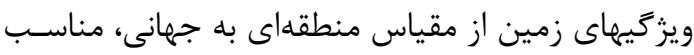

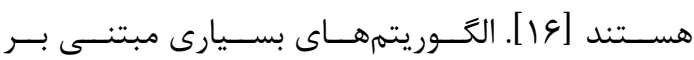
اين محصولات، براى برآورد تابش موج كوتاه طراحسى و

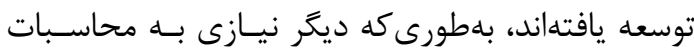

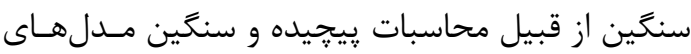

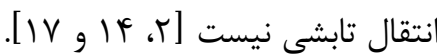

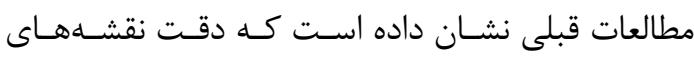
تابش موج كوتاه هنوز در بسيارى موارد رضـايت بخـش

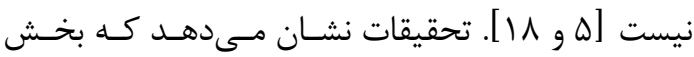

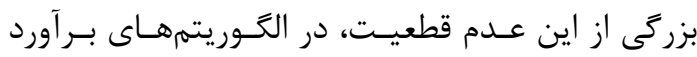
تابش موج كوتاه در شرايط بدون ابر، مرتبط با دادههاى ائ غيردقيق عمق إيتيكى هــواويز

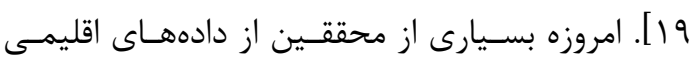

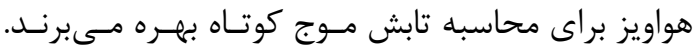

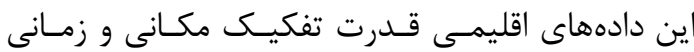
يايينى دارند ( إند درجه و ماهيانه) و ممكـن اسـت بـراى

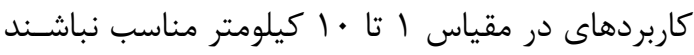
[ه1]]. در حال حاضر نياز به بررسى و مطالعه دقيق اثر هواويزها بر روى تـابش خورشـيدى در شـرايط آسـمان

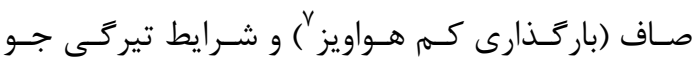

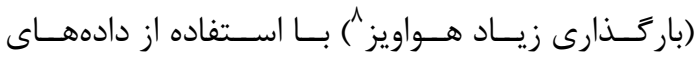

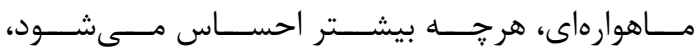

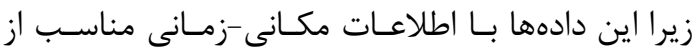

\footnotetext{
${ }^{6}$ Aerosol Optical Depth

${ }^{7}$ Low aerosol loading

${ }^{8}$ High aerosol loading
}

| - مقدمه

مجموع تابش خورشـيدى رسـيده بـه سـطح زمـين در

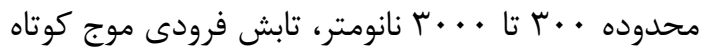
در ســح ' (DSSR) ناميـده مــى شــود و از دو مؤلفــهـ

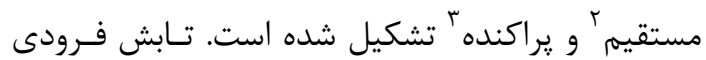
به سطح زمين، نقش اساسى در توازن انرزى بين جـو و

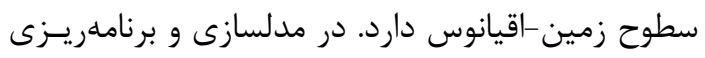

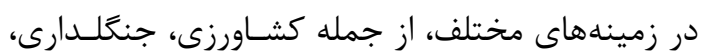
اقيانوس شناسى، هواشناسى و اقليم، اندازهگيرى مكانى

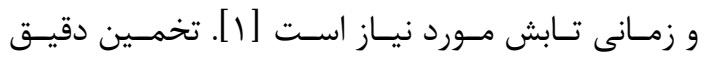

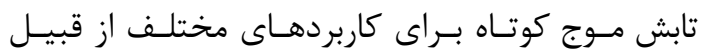

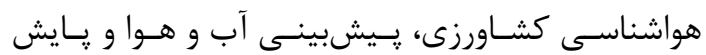
اقليم، بسيار ضرورى است و همجنين يك متغيـر مهـهم در بسيارى از مدلهاى عددى براى تخمين يارامترهايى بـى صرورى

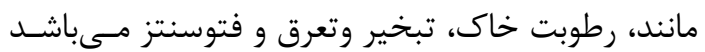

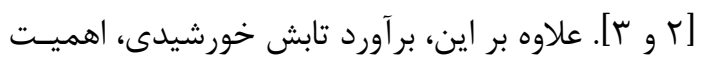

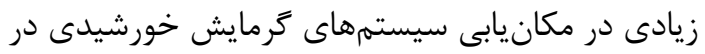

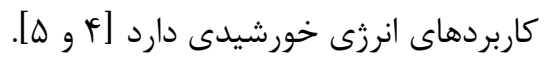

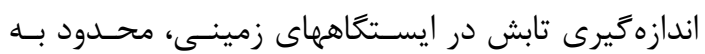

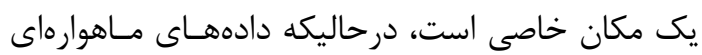

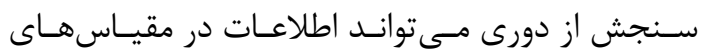
محلى تا جهـانى را در اختيـار كـاربران قـرار دهـد [ع]. بنابر اين مدل هاى بسيارى براى تخمين تابش موج كوتاه

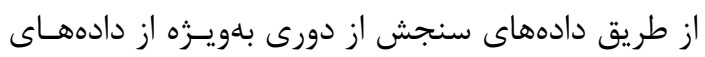

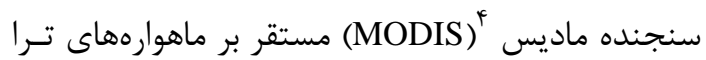

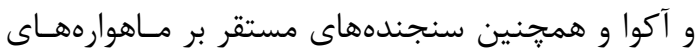

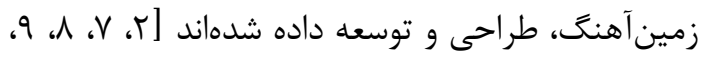

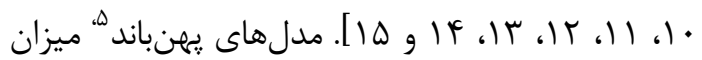

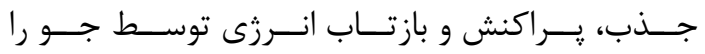

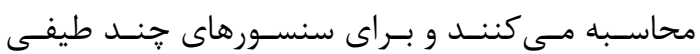

\footnotetext{
${ }^{1}$ Downward Surface Shortwave Radiation

${ }^{2}$ Direct

${ }^{3}$ Diffuse

${ }^{4}$ MODerate resolution Imaging Spectrometer

${ }^{5}$ Broadband
} 
بالا، تخمينهاى تابش موج كوتاه را بـا اسـتفاده از ايـن

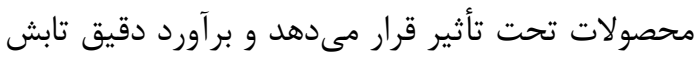

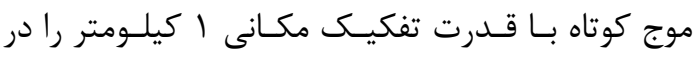

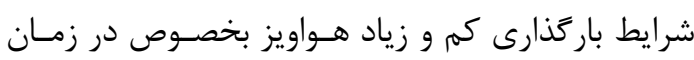

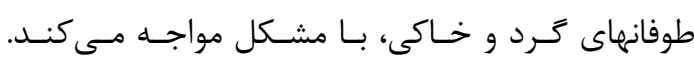

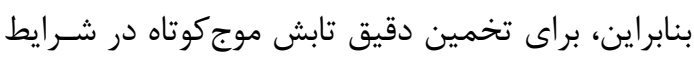

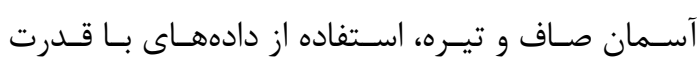

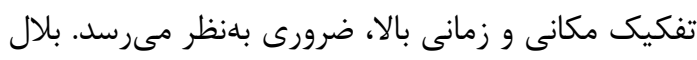

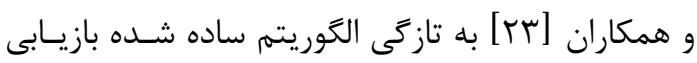

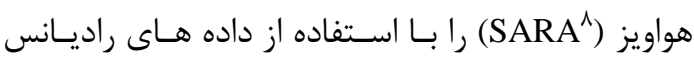

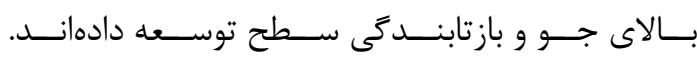

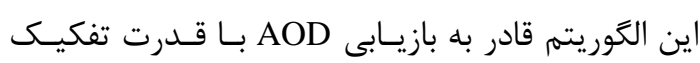

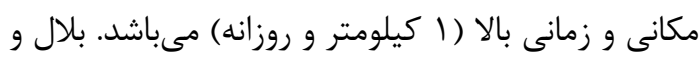

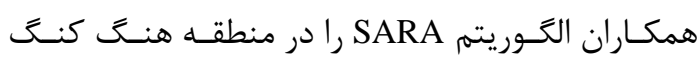

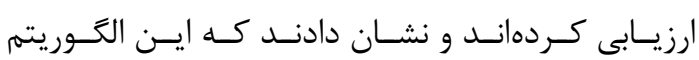

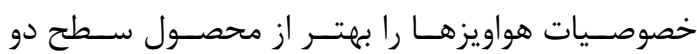

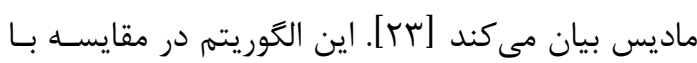

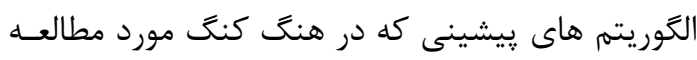

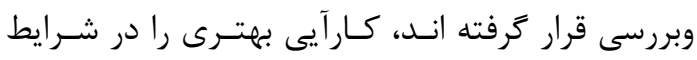

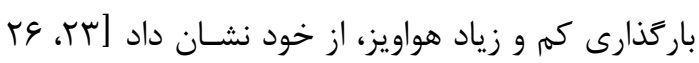

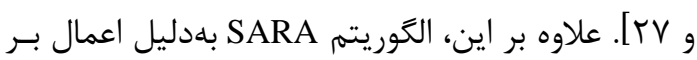

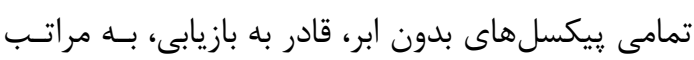

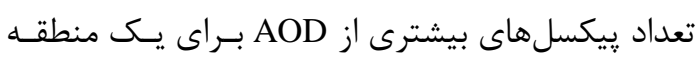

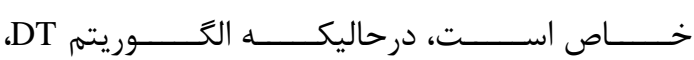

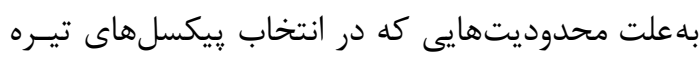

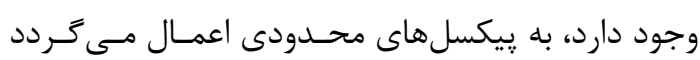

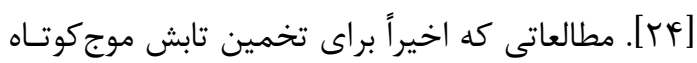

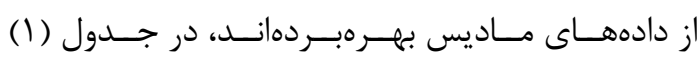

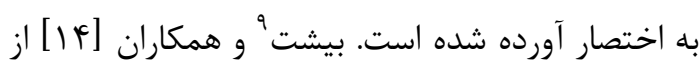

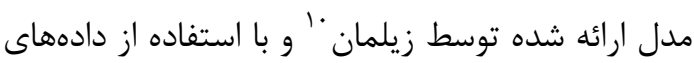

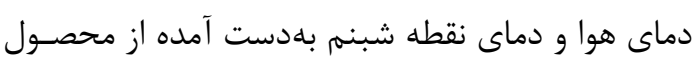

\footnotetext{
${ }^{8}$ Simplified Aerosol Retrieval Algorithm

${ }^{9}$ Bisht

${ }^{10}$ Zillman
}

توزيع هواويزها، مىتوانند ويزَيهاى دقيقى از اثر تابشى آنى آنها در اختيار كاربران قرار دهند.

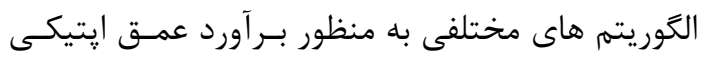

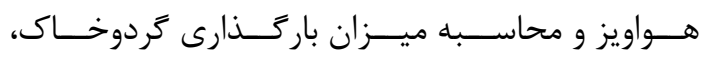
با استفاده از تكنيكهاى سنجش دورئ دورى توسعه داده شده

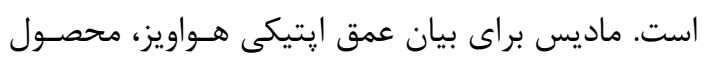

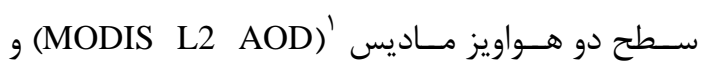

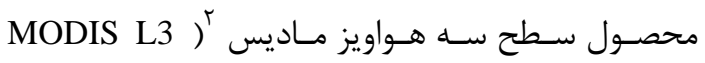

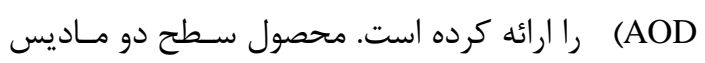

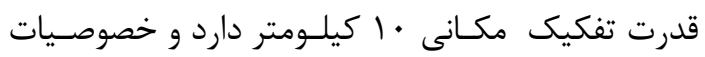

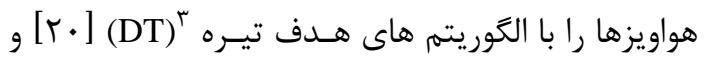

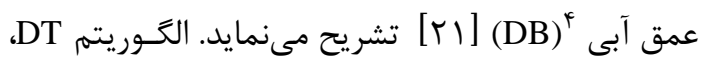

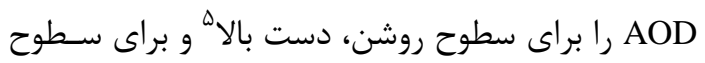

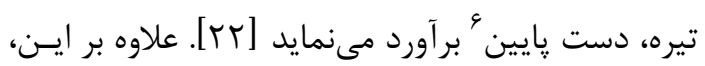

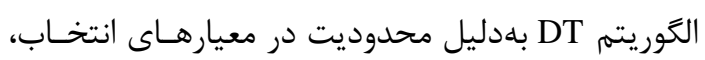

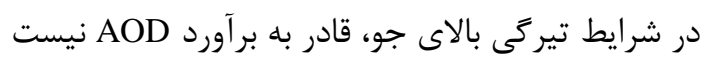

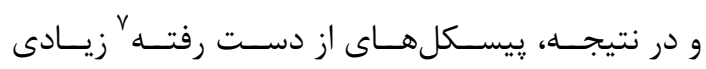

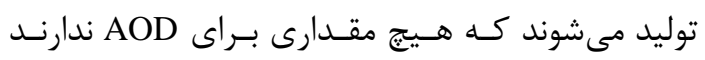

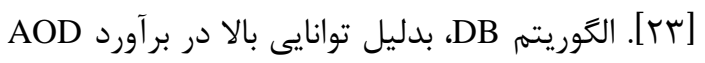

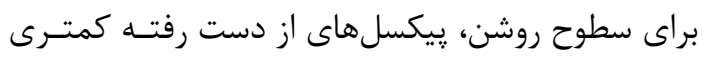

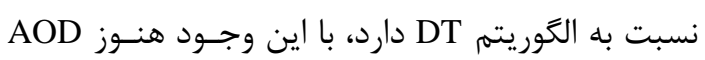

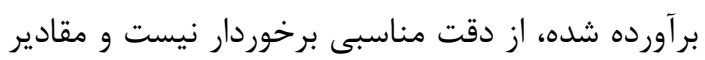

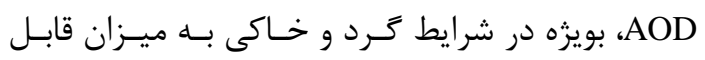

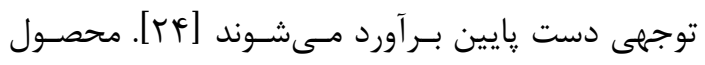

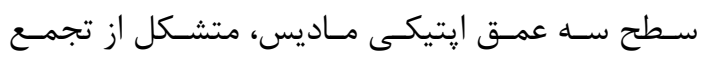

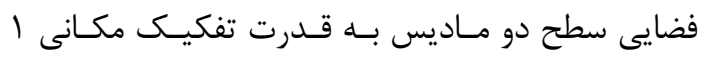

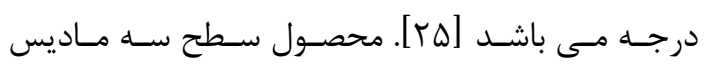

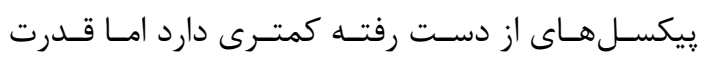

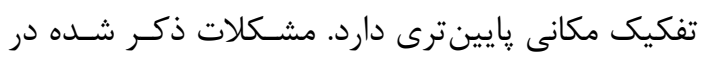

\footnotetext{
${ }^{1}$ MODIS Level 2 AOD

${ }^{2}$ MODIS Level 2 AOD

${ }^{3}$ Dark Target

${ }^{4}$ Deep Blue

${ }^{5}$ Overestimate

${ }^{6}$ Underestimate

${ }^{7}$ Missing pixels
} 
در روش ييشنهاد شده در اين تحقيق بهجاى استفاده از

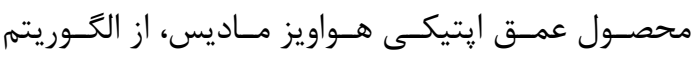
كA با استفاده از محصول راديانس بـالاى جـو و

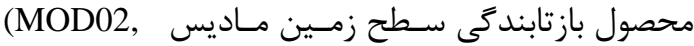

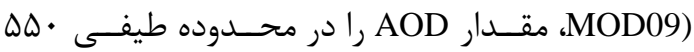

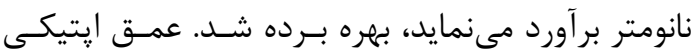
هواويز بهدست آمده با الخوريتم SARA AOD SARA ناميده مىشود. سيس براى محاسبه تابش موج كوتاه بـا

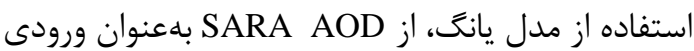
عمق إيتيكى هواويز اسـتفاده شـد. بــمنظظـور مقايسـه، محصول سطح دو و سه ماديس نيز براى محاسبه تابش

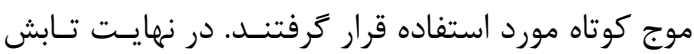
موج كوتاههاى بلدست آمده از اين سه نوع داده مختلف مورد

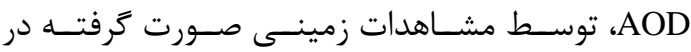
ايستگاه جيتگر، مورد ارزيابى قرار گرفتند. هدف اين تحقيق توسعه مدلى براى تخمين دقيق تابش

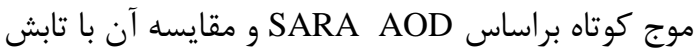

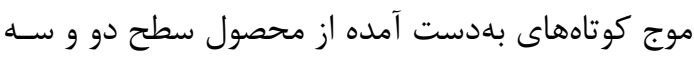

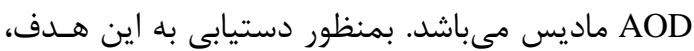

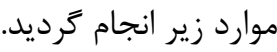

• تخمين تابش مـوج كوتـاه بـا اسـتفاده از مـدل

MODIS L2 ، يانـ براسـاس SARA AOD

MODIS L3 AOD, AOD

ارزيـابى تـابشهــاى بـهدسـت آمـده براسـاس

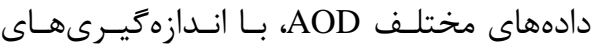

زمينى صورت گرفته توسط دسـتخاه يِيرانـومتر

مستقر در ايستخاه جيتخر

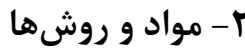

در اين بخش، ابتدا منطقه مورد مطالعـه معرفى شـده، سيس مشاهدات زمينى صـورت گرفتـهـ بـراى DSSR و

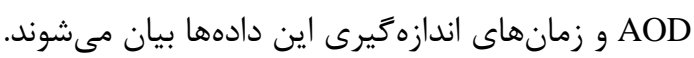
قسمت بعدى اين بخش بــه دادههـاى مـاهوارهاى مـورد

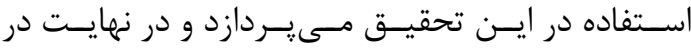

يروفايل جو مـاديس (MOD07)، تـابش مـوج كوتـاه را براى روزهاى بدون ابر برآورد نمودند. ريـو' و همكـاران

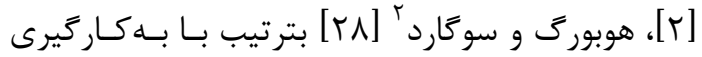

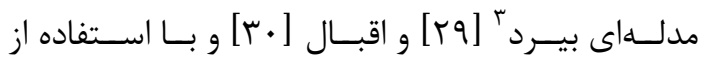
محصـول سـطح دو عمـق إيتيكىى هــواويز (MOD04)،

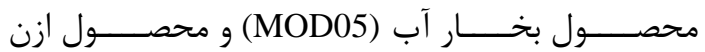
سنجنده ماديس، تابش موجكوتاه در سـطح (MOD07) را بهدست آوردند. هوانگ مدل توسعه يافته يانگ بهمراه محصول سطح دو و ســـ عمـق إتيكـى هــواويز (MOD04/MOD08)، محصـول

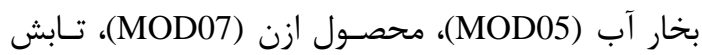

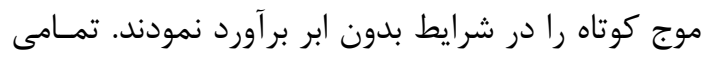

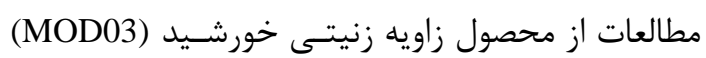
بهره بردند.

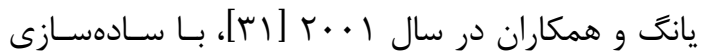

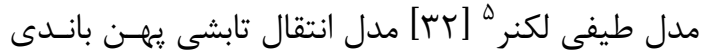
را طراحى و توسعه دادند. نتيجه ارزيابى ال مدل توسط

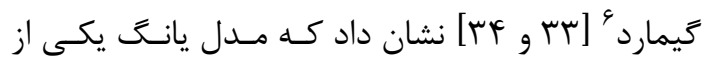
بهترين مدلهاى يههن باند در مقايسه با مدلهاى انتقال تابشى براى محاسبه تابش موج كوتاه در شــرايط بـدون بـائ

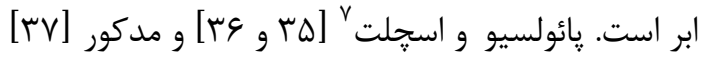
[rV] نيز، كار آيى بالاى ايسن مـدل را تأييـد نمـودهانـد.

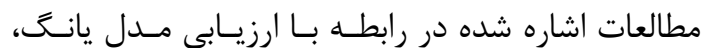

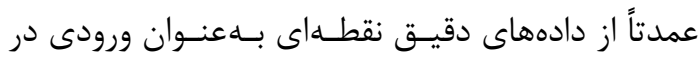
مدل بهره مىبرند. در تحقيق حاضـر نيـز از ايسن مـدل براى محاسبه تـابش مـوج كوتـاه در شـرايط بـدون ابــر

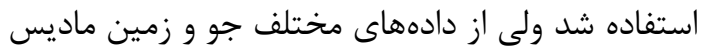
بعنوان ورودى استفاده گرديد (جدول ( ()).

\footnotetext{
${ }^{1}$ Ryu

${ }^{2}$ Houborg \& Soegaard

${ }^{3}$ Bird

${ }^{4}$ Huang

${ }^{5}$ Leckner

${ }^{6}$ Gueymard

${ }^{7}$ Paulescu and Schlett
} 
قسمتهاى بعدى، روشهاى استفاده شده، براى بازيابى DSSR و AOD

جدول ا: بر آورد تابش موجكوتاه با استفاده از دادههاى ماديس در مطالعات يِيشين و تحقيق حاضر

\begin{tabular}{|c|c|c|}
\hline محصولات داده هاى ماديس & 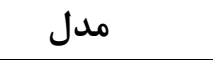 & تحقيق \\
\hline MOD03, MOD07 & 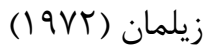 & بيشت و همكاران، ه · · \\
\hline MOD03, MOD04, MOD05, MOD07 & اقبال (r/91) & هوبورى و سو \\
\hline MOD03, MOD04, MOD05, MOD07 & بيرد (1919) & 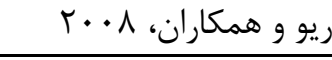 \\
\hline MOD03, MOD04/MOD08, MOD05, MOD07 & 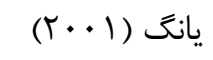 & هوانگ و همكاران، r ا • r \\
\hline MOD02, MOD03, MOD05, MOD07, MOD09 & 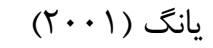 & تحقيق حاضر \\
\hline
\end{tabular}

نرمافزار آمارى SPSS كنترل شده و دادههـاى خـارج از

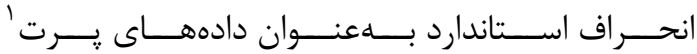

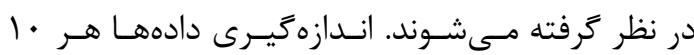

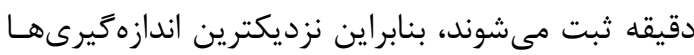
به زمانهاى گذر ماهواره ترا بهعنوان اندازهگيرى زمينى مربوطه درنظر گرفته مىشوند.

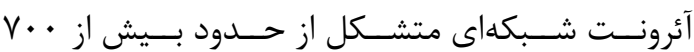
سانفتومتر كاليبره شده زمينى در سراسـر جهـان اسـت

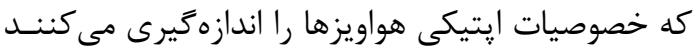

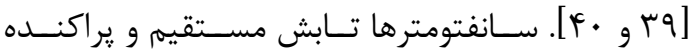

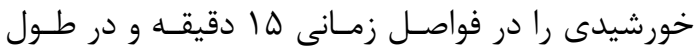

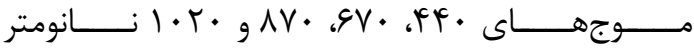
اندازهگيرى مى كنند و AOD در طول موجهاى مذبور با

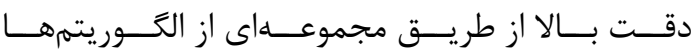

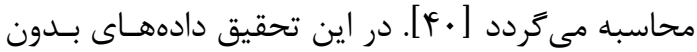

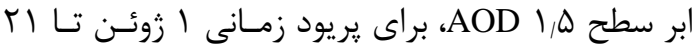

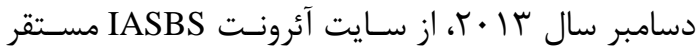
در دانشگاه تحصيلات تكميلى شهر زنجان (شكل (1) و (1)

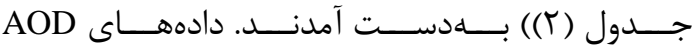

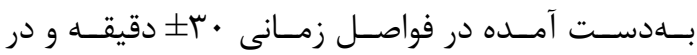

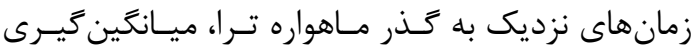

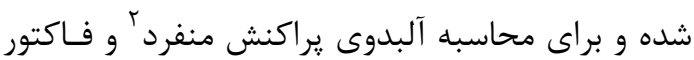

${ }^{1}$ Outlier

${ }^{2}$ Single Scattering Albedo (SSA)

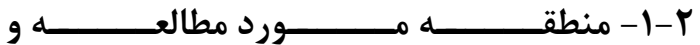
اندازهزيرى هاى زمينى

سايت جيتخر در دامنه جنوبى رشته كوههـاى البـرز در

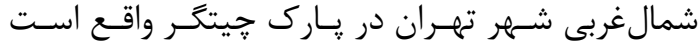

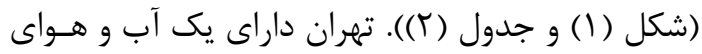
خشك (طبقه بندى اقليمى كوين: BSK)، از نـوع آب و

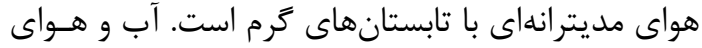
تهران تا حد زيادى از طريق موقعيت جغرافيايى آن كـهـ توسط رشته كوههاى بلند البرز از شمال و كوير مركزى لهري از جنوب احاطه شده است، تعريف مىشود. بهطور كلى مىتوان كفت تهران داراى آب و هواى معتدل در بهار و

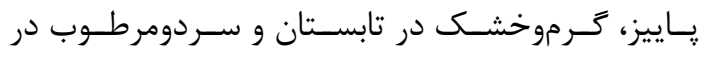

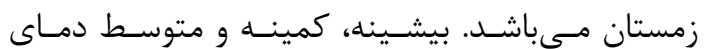

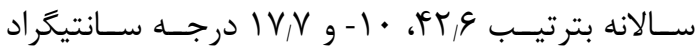

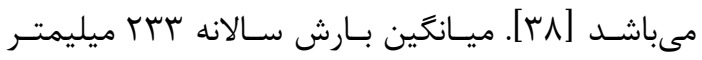
است. دادههاى سايت جيتــــ از سـازمان هواشناسـى كشـور

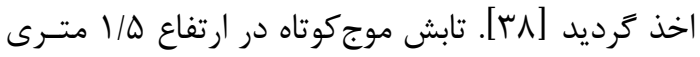

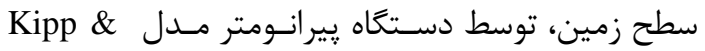
Zonen CMP6 انـدازهزيــرى مـىشــود (جـدول (r)).

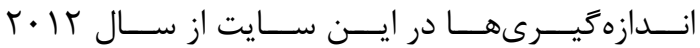

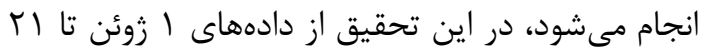

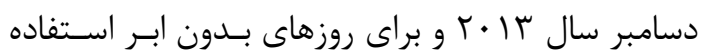

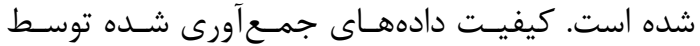




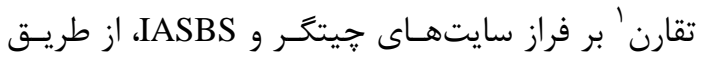

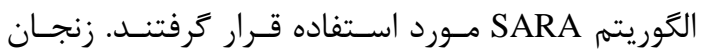
داراى آب و هواى نيمه خشك سرد (طبقلهندئ اقليمسى كوين: BSK)، با تابستانهاى گرم و زمستانهاى سرد و

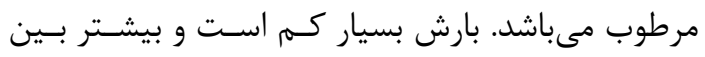

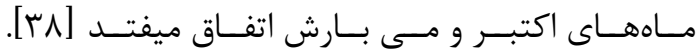
ميانگين دماى سالانه 11 درجـه سـانتيخراد و ميـانغين بارش سالانه هال الميليمتر است. 


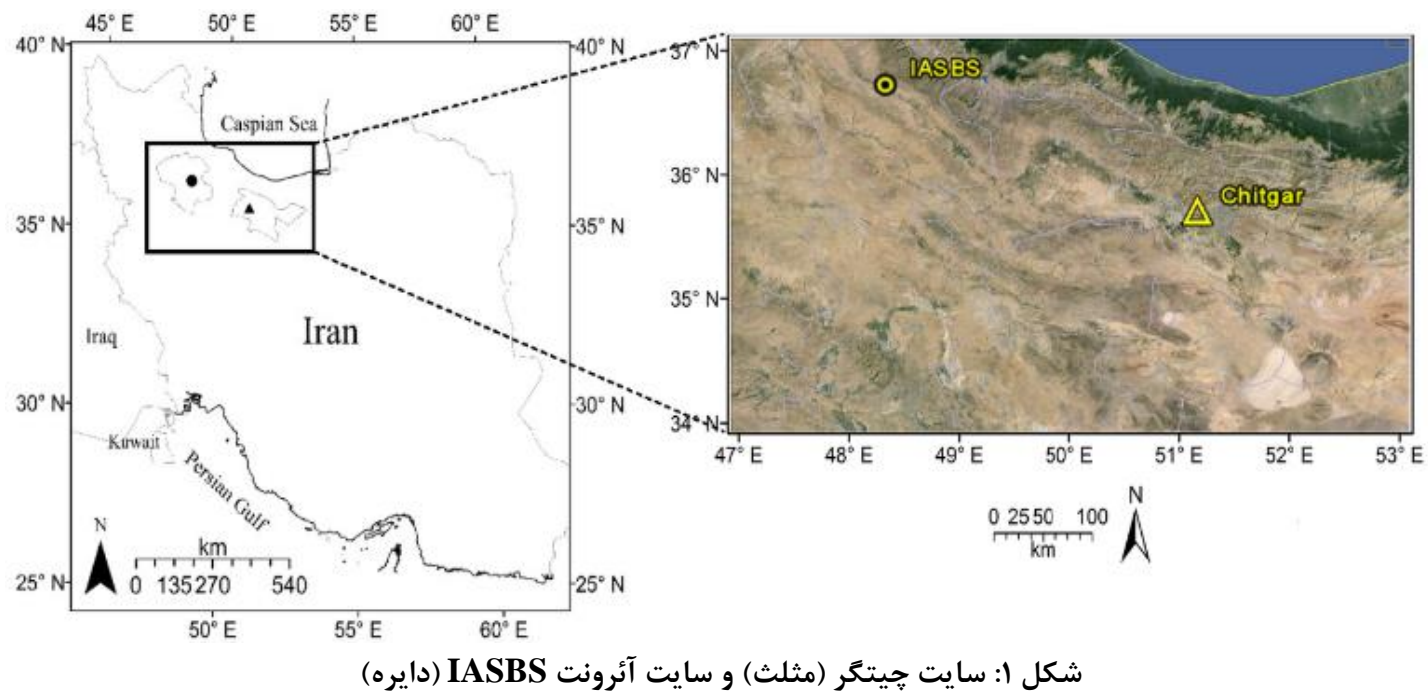

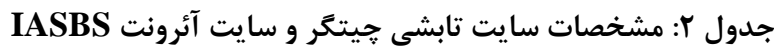

\begin{tabular}{|c|c|c|c|c|}
\hline 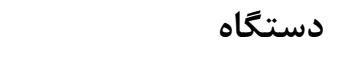 & ار تفاع (متر) & عرض جغرافيايى & طول جغر افيايى & 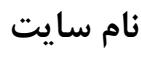 \\
\hline بيرانومتر مدل CMP6 & $1 \mu \cdot \Delta$ & & • ا له درجه شرقى & جيتخر \\
\hline سانفتومتر مدل CIMEL & $1 \Lambda \cdot \Delta$ & • • ب درجه شمالى & • • د درجه شرقى & IASBS \\
\hline
\end{tabular}

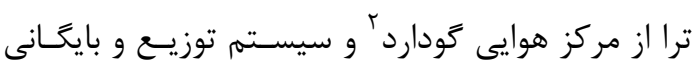

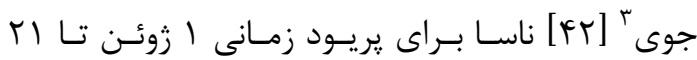

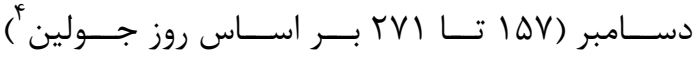
استخراج گرديدند. محصولات مختلف دادههاى مـاديس و يارامترهاى مورد استفاده، بهمراه قدرت تفكيك مكانى

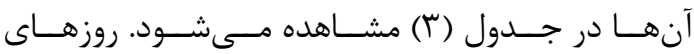

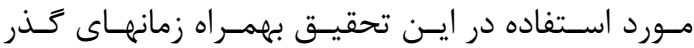

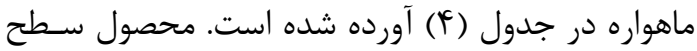
دو يروفايل جو MOD07، سطح دو عمق إتيكى هواويز MOD04 و سطح سه عمـق إِتيكى هـواويز MOD08

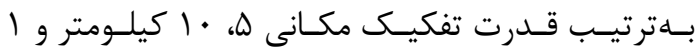
درجه دارند. بنابراين هر سه به قدرت تفكيك مكـانى 1

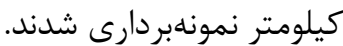

${ }^{2}$ Goddard Space Flight Center (GSFC)

${ }^{3}$ Atmosphere Archive and Distribution System (LAADS)

${ }^{4}$ Julian day

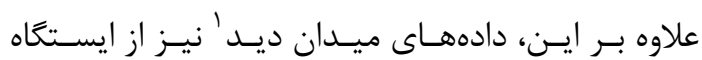

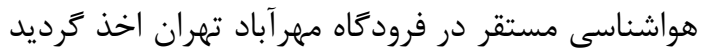

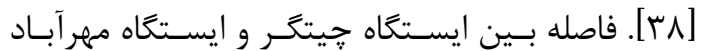

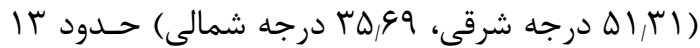

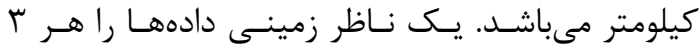
ساعت اندازمخيرى مى كند. دادهاى ميدان ديد معمـولاً

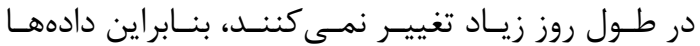
براى يك روز ميانگين گيرى مسى شـوند. بـراى محاســبه

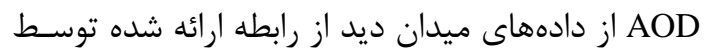

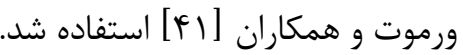

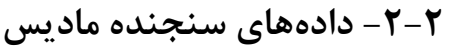
محصول سطح يك، داده راديانس بالاى جو MOD02 و

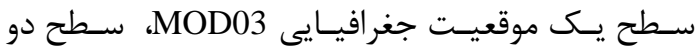

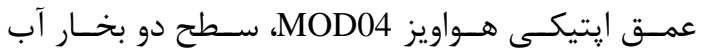

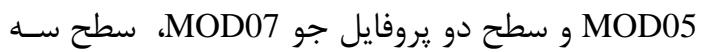
عمق ايتيكى هواويز MOD08، سنجنده ماديس ماهواره

${ }^{1}$ Visibility 
جدول r: محصولات دادههاى ماديس مورد استفاده در اين تحقيق

\begin{tabular}{|c|c|c|c|c|}
\hline مدل يا الخوريتم & يار امتر هاى مورد استفاده & قدرت تفكيك & اختصارى & محصول ماديس \\
\hline SARA & راديانس بالاى جو باند سبز & ا كيلومتر & MOD02 & 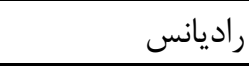 \\
\hline يانَ و SARA & ارتفاع، زواياى زنيتى و آزيموتى & ا كيلومتر & MOD03 & موقعيت جغرافيايى \\
\hline 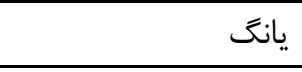 & عمق ايتيكى هواويز در •ه نانومتر & 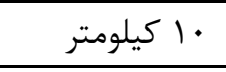 & MOD04 & عمق ايتيكى هواويز \\
\hline 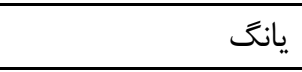 & ميزان بخار آب م & ا كيلومتر & MOD05 & بخار آب \\
\hline 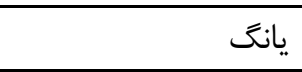 & 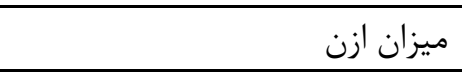 & 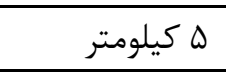 & MOD07 & يروفايل جو \\
\hline يانت & عمق ايتيكى هواويز در •ه نانومتر & ا درجه & MOD08 & شبكه بندى جو \\
\hline SARA & بازتابندگى سطح باند سبز & ا كيلومتر & MOD09 & بازتابندگى سطح \\
\hline تعيين روزهاى بدون ابر & دماى سطح & ا كيلومتر & MOD11 & دماى سطح زمين \\
\hline
\end{tabular}

جدول f: روزهاى مورد مطالعه در اين تحقيق و زمانهاى كذر ماهواره از منطقه

\begin{tabular}{|c|c|c|c|}
\hline 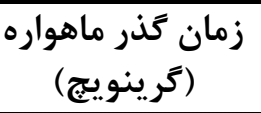 & (روز جقويمى جولين) & $\begin{array}{c}\text { زمان كَذر ماهواره } \\
\text { (كرينويج) }\end{array}$ & (روز جقويمى جولين) \\
\hline $1 \cdot: V$ & F جولاى (ه ·r) & $1 \cdot: V$ & צ'زوئن (lQV) \\
\hline$V: \cdot \Delta$ & 1 ا آگوست (• • & $1 \cdot: V$ & r زوئن (IVT) \\
\hline $1 \cdot: V$ & هT آكوست (TrV) & $V: \bullet \Delta$ & ا جولاى (IAr) \\
\hline$V: Y \Delta$ & ^ سيتامبر (I) & $\Delta \cdot: \bigvee$ & r جولاى (INH) \\
\hline$V: l^{\mu}$ & 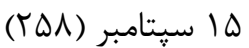 & $V: T^{2}$ & F جولاى (1/D) \\
\hline$V: \bullet \Delta$ & 9 سيتامبر (T\&Y) & V:Yd & צجولاى (IAV) \\
\hline$V: I^{\prime}$ & rr سيتامبر (\$\&) & $V: 1 \cdot$ & ^ جولاى (1/9) \\
\hline$V: 1$. & צr سيتامبر (T9) & V:r. & سا جولاى (194) \\
\hline \multirow[t]{2}{*}{$V: \cdot \cdot$} & N سيتامبر (TVI) & $V: \cdot \Delta$ & IV جولاى (191) \\
\hline & & $V: Y \Delta$ & rr جولاى (r.r) \\
\hline
\end{tabular}

تقــارن در روز بازيـابى و بــر فـراز يـــ منطقـه وسـيع

تغيير نمى كنند [بr]. r-r - بازيابى AOD با استفاده از الكوريتم SARA

(SARA AOD)

الخوريته SARA (رابطــه (1) (1) بـر اسـاس هندسـه ديسد

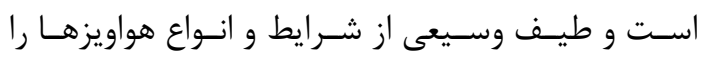

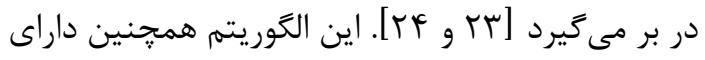

سه فرض است: (1) سطح لامبرتى اسـت، (r) تقريسب

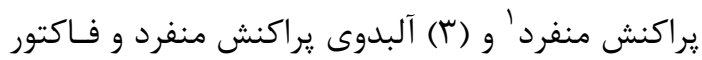

${ }^{1}$ single scattering approximation 
$\tau_{a, \lambda}=\frac{4 \mu_{s} \mu_{v}}{\omega_{0} P_{a\left(\theta_{S}, \theta_{v}, \phi\right)}}\left[\rho_{T O A\left(\lambda, \theta_{s}, \theta_{v}, \phi\right)}-\rho_{R a y\left(\lambda, \theta_{s}, \theta_{v}, \phi\right)}-\frac{e^{-\left(\tau_{R}+\tau_{a, \lambda}\right) / \mu_{s}} e^{-\left(\tau_{R}+\tau_{a, \lambda}\right) / \mu_{v}} \rho_{s\left(\lambda, \theta_{S}, \theta_{v}, \phi\right)}}{1-\rho_{s\left(\lambda, \theta_{S}, \theta_{v}, \phi\right)}\left(0.92 \tau_{R}+(1-g) \tau_{a, \lambda}\right) \exp \left[-\left(\tau_{R}+\tau_{a, \lambda}\right)\right]}\right]$

$\rho_{R a y\left(\lambda, \theta_{s}, \theta_{v}, \phi\right)}=\frac{\omega_{0} \tau_{R} P_{R\left(\theta_{s}, \theta_{v}, \phi\right)}}{4 \mu_{s} \mu_{v}} \quad$ (广) تابع فاز هواويز بيانكر توزيع زاويهاى نور يــراكنش شــده

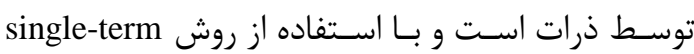
Henyey-Greenstein

$$
P_{a\left(\theta_{S}, \theta_{v}, \phi\right)}=\frac{1-g^{2}}{\left[1+g^{2}-2 g \cos (\pi-\Theta)\right]^{3 / 2}} \quad \text { (ब) }
$$

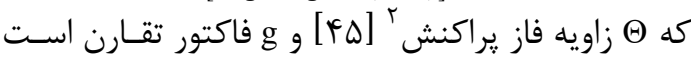

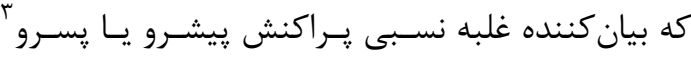
است و در بسيارى از مدلهاى هواويز مقدار اين يارامتر

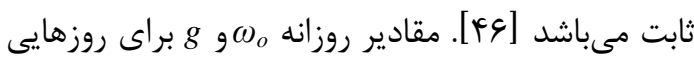

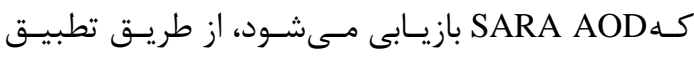

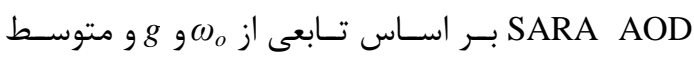

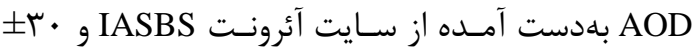

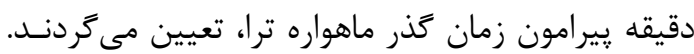

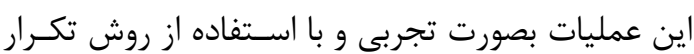
نقطه ثابت تطابق بهدست آيد، انجام مىشود. سيس وف و و و، بهمراه

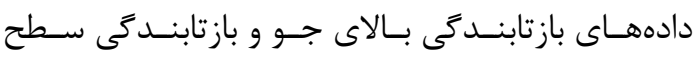

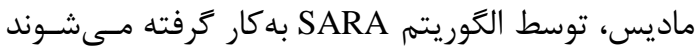
تا AOD با قدرت تفكيك مكـانى ا كيلـومتر در سـايت جيتخر و مناطق اطراف آن براى لحظه كذر ماهواره تـرا

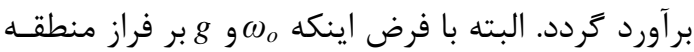
مورد مطالعه و در طول روز بازيابى، تغييرى نمسى كننـد.

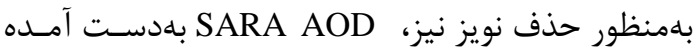

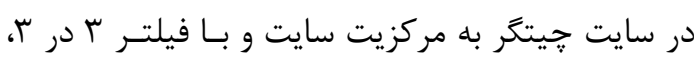

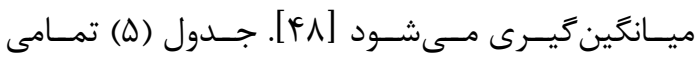

\footnotetext{
${ }^{2}$ Scattering phase angle

${ }^{3}$ Forward and back scattering

${ }^{4}$ Fixed Point Iteration (FPI)
}

كه ريلى، م بازتابند $\rho_{\text {Ray }}$

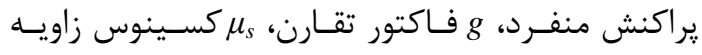
زنيتى خورشيد،

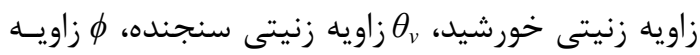

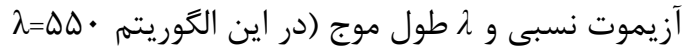
نانومتر، باند سبز ماديس) مىباشد.

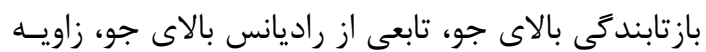

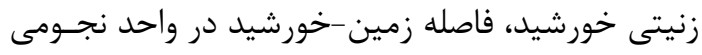

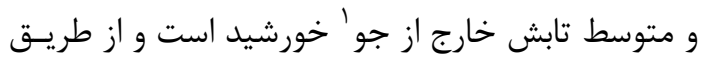
رابطه (r) تخمين زده مىشود.

$\rho_{T O A(\lambda)}=\frac{\pi L_{T O A(\lambda)} d^{2}}{E S U N_{\lambda} \mu_{S}}$

(T) رابطه

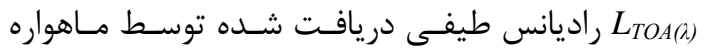
بالاى جو، ESUN متوسط تابش خارج از جو خورشيد و d فاصله زمين -خورشيد در واحد نجومى است. عمق ايتيكى ريلى عمدتاً وابسته به فشار محيط و ارتفاع

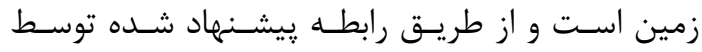

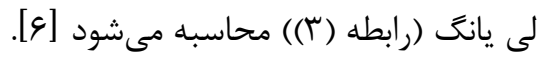
$\tau_{R}=\frac{P_{z}}{P_{0}}(0.00864+6.5 * \quad$ رابط $\left.10^{-6} * z\right) \lambda^{-(3.196+0.074 \lambda+0.05 / \lambda)}$ Pشار محيط نسبت به ارتفاع برحسبـ ميلسىبـار، $P_{z}$ فشار در سطح متوسط دريا و برابر سا • ا ميلىبار است،

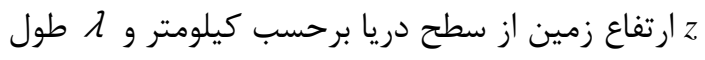
موج برحسب ميكرومتر مىباشد.

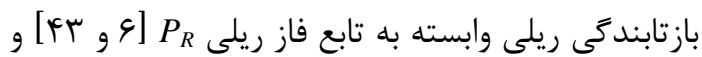

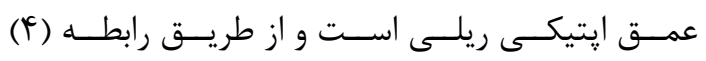
بهدست مى آيد.

${ }^{1}$ exoatmospheric 


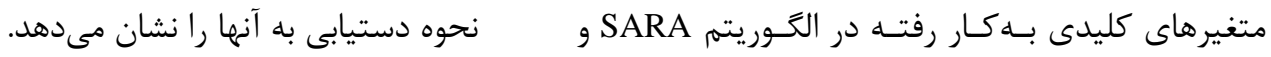

جدول ه: متغيرهاى كليدى در الكَوريتم SARA

\begin{tabular}{|c|c|c|}
\hline بهدست آمده از: & يار امتر & عبارت \\
\hline محصول موقعيت جغرافيائى ماديس (MOD03) & زاويه زآزيتى خورشيد، زاويسه زنيتـى ســنجنده، & $z_{g} \phi ، \theta_{v} \cdot \theta_{s}$ \\
\hline$\theta_{v}, \theta_{s}$ & كسينوس زاويه زنيتـى خورشـيد و كسـينوس زنسيت & $\mu_{v}, \mu_{s}$ \\
\hline مقادير ارائه شده توسط لى يانگ [ع] & متوسط تابش خارج از جو خورشيد & $E S U N_{\lambda}$ \\
\hline رابطه ارائه شده در [•r] و روز جولين & فاصله زمين-خورشيد در واحد نجومى & $d$ \\
\hline$z$ & فشار محيط نسبت به ارتفاع برحسب ميلىبار & $P_{z}$ \\
\hline 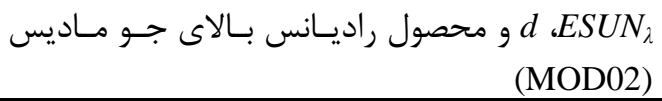 & بازتابندگى بالاى جو (باند سبز) & $\rho_{T O A}$ \\
\hline محصول بازتابندگى سطح ماديس (MOD09) & بازتابندگى سطح زمين (باند سبز) & $\rho_{s}$ \\
\hline$z, P_{z}$ & عمق ايتيكى ريلى & $\tau_{R}$ \\
\hline$\tau_{R}$ & تابع فاز ريلى & $P_{R}$ \\
\hline$\mu_{v} g \mu_{s} ، P_{R} \quad \tau_{R}$ & بازتابندگى ريلى & $\rho_{\text {Ray }}$ \\
\hline 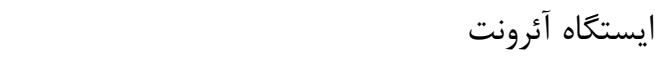 & آلبدوى يراكنش منفرد و فاكتور تقارن & $g, \omega_{o}$ \\
\hline$\phi, \theta_{v} \theta_{s}$ & زاويه فاز يراكنش & $\Theta$ \\
\hline$\Theta, g$ & تابع فاز هواويز & $P_{a}$ \\
\hline$g, \omega_{o} ، P_{a} ، \tau_{R} \rho_{R a y} \iota \rho_{s} \iota \rho_{T O A} \cdot \mu_{v}, \mu_{s}$ & عمق إيتيكى هواويز & $\tau_{a}$ \\
\hline
\end{tabular}

r-ه - بازيابى تابش موج كوتاه با استفاده از مــدل يانگَ

تابش موج كوتاه برحسب حذردهى كل' آ بـا رابطـه (V) بيان مىشود. $D S S R=E_{0} \mu_{s} \tau / d^{2}$

(V) رابطه

كه

ضريب گذردهى كل با استفاده از مـدل يانـَ و بهمـراه محصـولات زمينـى و جــو مـاديس محاسـبه مسى شـود.

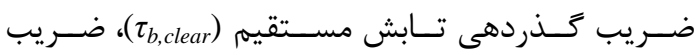

\footnotetext{
${ }^{1}$ Total transmittance
}

r-F - بازيابى AOD با استفاده از اندازهخيرىهاى

ميدان ديد (Visibilty AOD)

دادههـاى ميــدان ديـد ثبـت شـده در سـايت فرودگَـاه

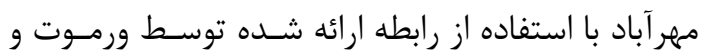

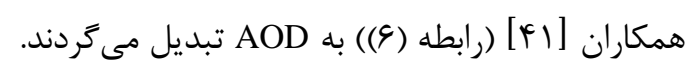
$V=3.9449 /\left(\mathrm{AOD}_{550}-0.08498\right) \quad$ رابطه (ع) كـه V ميـدان ديـد برحسـب كيلـومتر، AOD

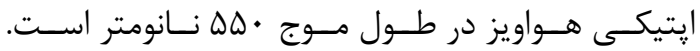
اين رابطه براى AOq

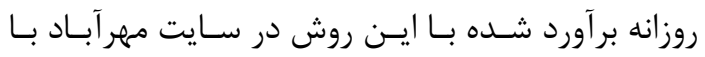
MODIS L3 وMODIS L2 AOD ،SARA AOD AOD 
مختلـف ؟ زاويـهـ زنيتـى خورشـيد، سـتونى كلـى ازنَّ

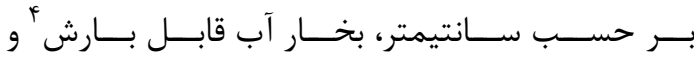

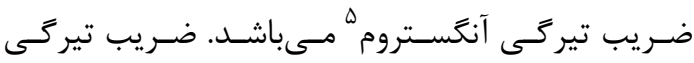

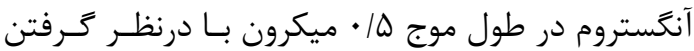

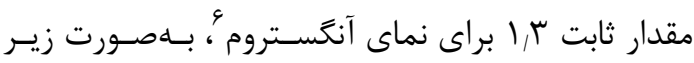
تعيين مى

$\beta=0.5^{1.3} \mathrm{AOD}(0.5)$

رابطه (1)

كه (0.5)، AOD(0. عمق إيتيكى هوايز در طـول مـوج هر • ميكرون مىباشد. جدول (9) تمامى متغيرهـاى كليـدى

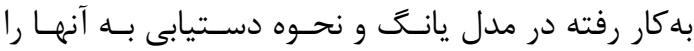
نشان مى دهد.

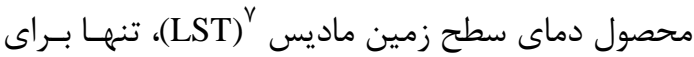
ييكسلهاى بدون ابر مقدار دارد، بنابراين در اين تحقيق

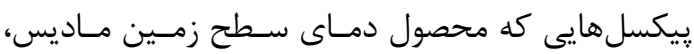
براى آن مقدار دارد، بهعنوان شاخص شرايط بـدون ابــر

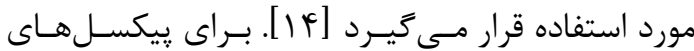

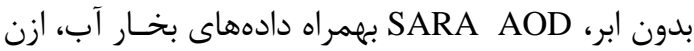
و اطلاعات هندسى بلهدست آمـده از مـاديس بــهعنـوان دادهاى ورودى الگوريتهم يانگ جهت برآورد تابش موج

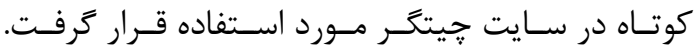
تابش بهدسـت آمـده از ايسن روش، تـابش مـوج كوتـاه

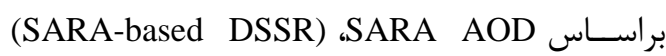

$$
\text { ناميده مى شود. }
$$

$$
\begin{aligned}
& \text { كذردهى تابش يراكنده ( } \\
& \text { ( } \left.\tau_{\text {clear }}\right)
\end{aligned}
$$

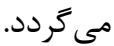

$$
\begin{aligned}
& \tau_{b, \text { clear }}=\tau_{o z} \tau_{w} \tau_{g} \tau_{r} \tau_{a}-0.013 \\
& \text { (1) رابطه } \\
& \tau_{d, \text { clear }}=0.5\left[\tau_{o z} \tau_{g} \tau_{w}\left(1-\tau_{r} \tau_{a}\right)\right. \\
& +0.013] \\
& \text { ) رابطه (9) }
\end{aligned}
$$$$
\tau_{\text {clear }}=\tau_{b, \text { clear }}+\tau_{d, \text { clear }}
$$$$
\text { رابطه (•) }
$$$$
\text { كـــهـ }
$$

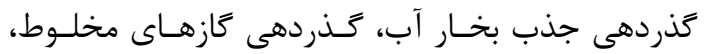$$
\text { كذردهى يراكنش ريلـى و كَذردهى ناشـى از جـذب و }
$$

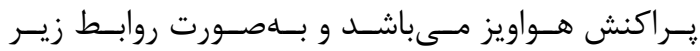

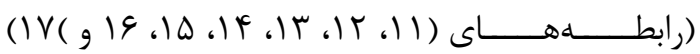
بيان مى رَرند.

$$
\begin{aligned}
& \tau_{o z}=\exp \left[-0.0365(m l)^{0.7136}\right] \quad \text { (II) رابطه } \\
& \text { رابطه (T) }
\end{aligned}
$$$$
\tau_{w}=\min [1.0,0.909-0.036 \ln (m w)]
$$$$
\tau_{g}=\exp \left(-0.0117 m_{c}^{0.3139}\right)
$$

رابطه (IT)

$\tau_{r}$

$=\exp \left[-0.00873517 m_{c}(0.547\right.$

$+0.014 m_{c}-0.00038 m_{c}^{2}+4.6$

رابطه (If) $\left.\times 10^{-6} \mathrm{~m}_{c}^{3}\right)^{-4.08}$ ]

$$
\begin{aligned}
& \tau_{a} \\
& =\exp \{-\mathrm{m} \beta[0.6777 \\
& +0.1464(\mathrm{~m} \beta) \\
& \left.\left.-0.00626(\mathrm{~m} \beta)^{2}\right]^{-1.3}\right\}
\end{aligned}
$$

رابطه (19)

$$
m=\left(\cos \theta+0.15(\theta+3.885)^{-1.253}\right)^{-1}
$$

$m_{c}=m p / p_{0}$

(IV) (1) (1)

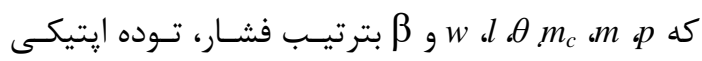

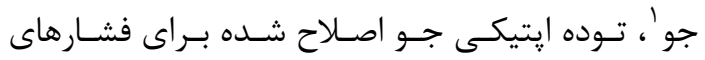

3 Total Ozone Column
${ }^{3}$ Tressure-corrected optic

${ }^{4}$ Perceptible water content

${ }^{5}$ Angstrom turbidity coefficient

${ }^{6}$ Angstrom exponent

${ }^{7}$ Land Surface Temperature

${ }^{1}$ Optical air mass 
جدول 9: متغيرهاى كليدى در مدل يانَ

\begin{tabular}{|c|c|c|}
\hline بهدست آمده از: & 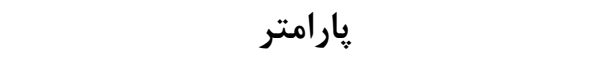 & 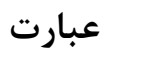 \\
\hline محصول موقعيت جغرافيائى ماديس (MOD03) & زاويه زنيتى خورشيد و ارتفاع & $z g$ \\
\hline$\theta$ & كسينوس زاويه زنيتى خورشيد & $\mu_{s}$ \\
\hline$z$ & فشار هوا & $P$ \\
\hline$\theta$ & توده إيتيكى جو & $m$ \\
\hline$P, m$ & توده ايتيكى جو اصـلاح شــده بـراى فشـارهاى & $m_{c}$ \\
\hline مقادير ارائه شده توسط لى يانگ [ع] & تابش فرودى بالاى جو در واحد نجومى يك & $E_{0}$ \\
\hline m و داده ستون كلى ازن ماديس (MOD07) & كذردهى جذب ازن & $\tau_{o z}$ \\
\hline m و داده ميزان بخار آب ماديس (MOD05) & كذردهى جذب بخار آب & $\tau_{w}$ \\
\hline$m_{c}$ & كذردهى گازهاى مخلوط & $\tau_{g}$ \\
\hline$m_{c}$ & كذردهى : كراكنش ريلى & $\tau_{r}$ \\
\hline 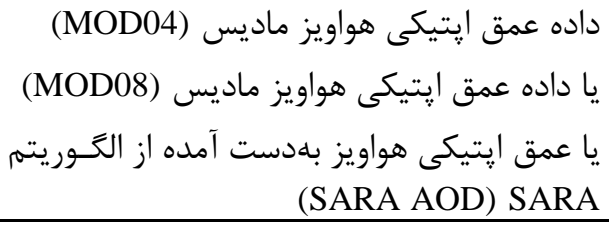 & ضريب تيركى آنخستروم & $\beta$ \\
\hline$\beta, m$ & كذردهى ناشى از جذب و يراكنش هواويز & $\tau_{a}$ \\
\hline$\tau_{a}, \tau_{r}{ } \tau_{g}{ }^{\prime} \tau_{w} \cdot \tau_{o z}$ & ضريب گذردهى تابش مستقيم & $\tau_{b, \text { clear }}$ \\
\hline$\tau_{a}, \tau_{r} \tau_{g}{ } \tau_{w} \cdot \tau_{o z}$ & ضريب حذردهى تابش يراكنده & $\tau_{d, \text { clear }}$ \\
\hline$\tau_{d, \text { clear }}, \tau_{b, \text { clear }}$ & ضريب گذردهى كل & $\tau_{\text {clear }}$ \\
\hline$\tau_{\text {clear },}, \mu_{s} ، E_{0}$ & تابش موج كوتاه فرودى در سطح & $D S S R$ \\
\hline
\end{tabular}

based DSSR) آمده از هركدام از دادههاى مختلف عمق إتيكىى، بـراى

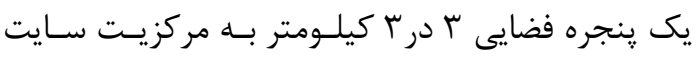

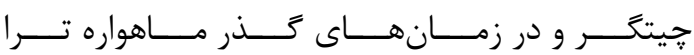
ميانگَين گيرى مسى شـوند. شـكل (r) ديـاكرام تخمـين

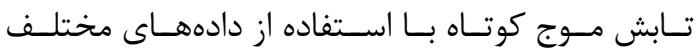

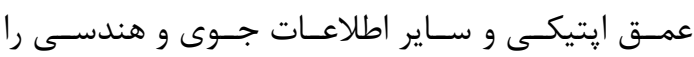
بهاختصار نمايش مى دهد.
بهمنظـور مقايسـه، MODIS L2 AOD و MODIS L3

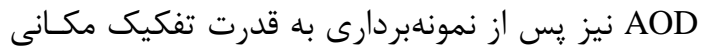
ا كيلومتر، بهمراه ساير اطلاعات جوى و هندسى جهت لهرت برآورد تابش مـوج كوتــاه مـورد اسـتفاده قـرار زرفتنــد.

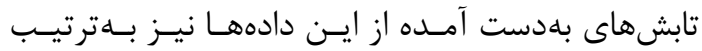
تابش موج كوتـاه براسـاس محصـول سـطح دو مـاديس MODIS L2-based DSSR) براسـاس محصـول ســطح سـه مـاديس-MODIS L33) 


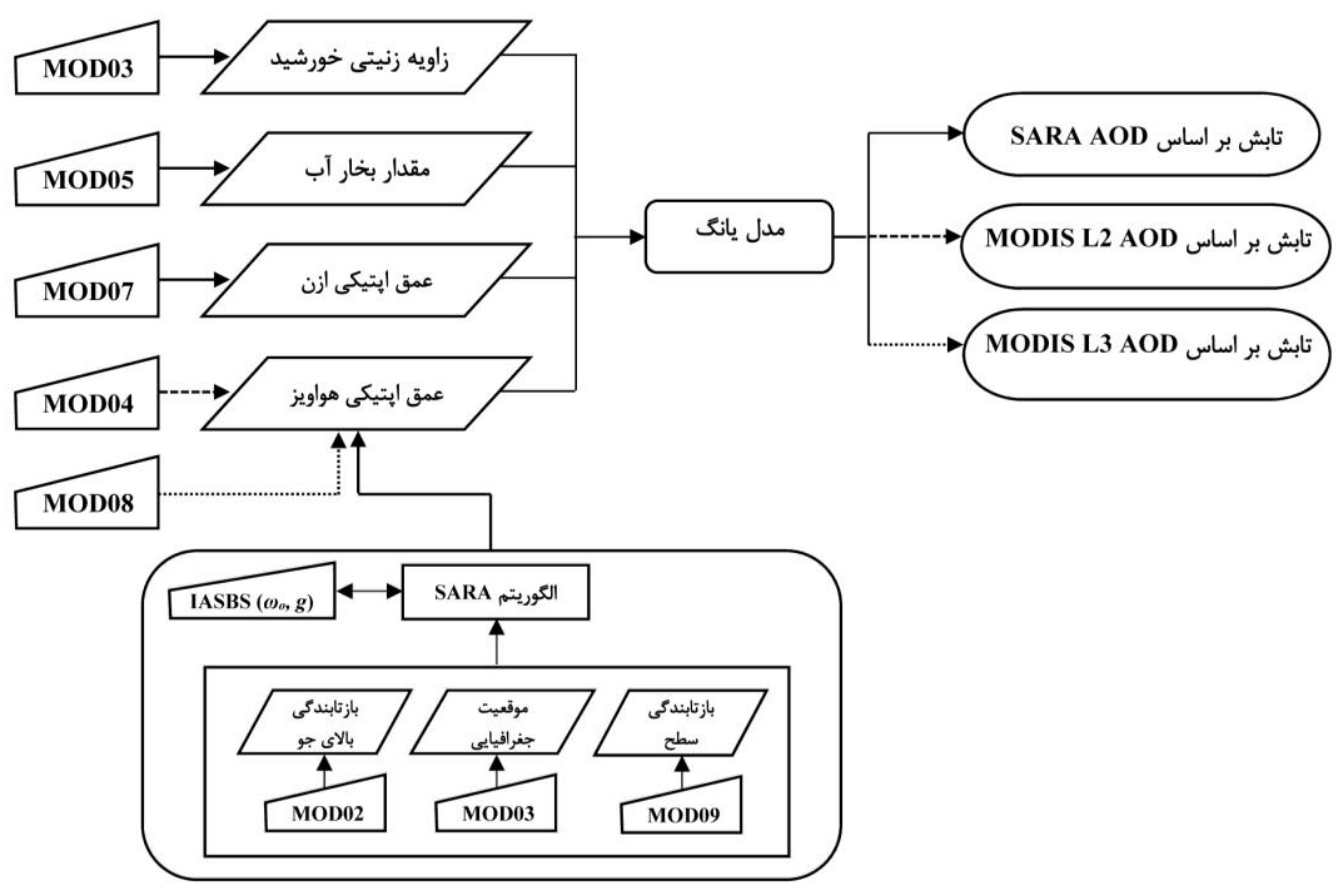

شكل ז: دياكرام تخمين تابش موج كوتاه بر اساس MODIS L2 AOD (MOD04) SARA AOD و و

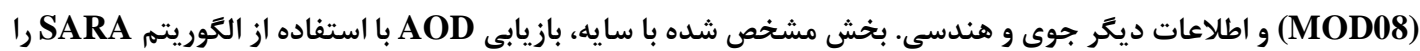
نشان مى دهد، بطوريكه

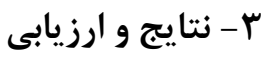

ب- - مقايسه AOD هاى بر آورد شــده در سـايت

$$
\text { مهر آباد }
$$

MODIS، شكل ب-الف، ب و ج مقايسه AOD ب ا MODIS L3 AOD g L2 AOD

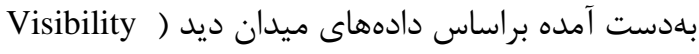

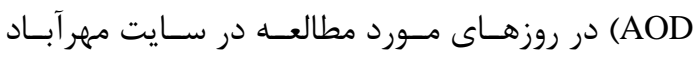

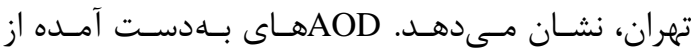

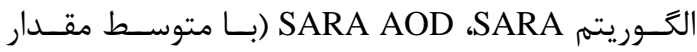

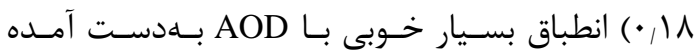

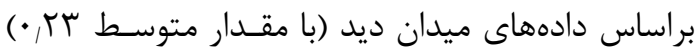
دارند، درحاليكه محصول MODIS L2 AOD، (با مقدار متوسط \ץ, •) مقـادير عمـق إيتيكى را تحـت شـرايط

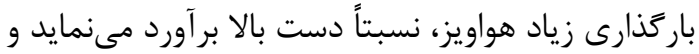

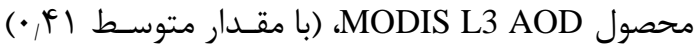
تحت هردو شـرايط باركــارى زيـاد و كـم، دسـت بـالا
براى اعتبارســنى تـابشهــاى بــرآورد شــده در سـايت

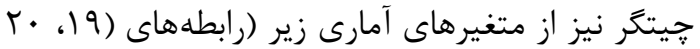

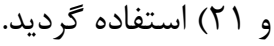
رابطه (19) $R^{2}=$ $\sum_{i=1}^{n}\left(E_{i}-\bar{E}\right)\left(O_{i}-\bar{O}\right) / \sum_{i=1}^{n}\left(E_{i}-\bar{E}\right)^{2} \sum_{i=1}^{n}\left(O_{i}-\bar{O}\right)^{2}$

$$
\begin{array}{ll}
\operatorname{RMSE}=\left[\frac{1}{n} \sum_{i=1}^{n}\left(E_{i}-O_{i}\right)^{2}\right]^{1 / 2} & (\text { ر ر ابطه (T) }
\end{array}
$$

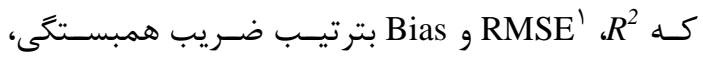

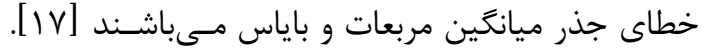
E و O Oابش تخمين و اندازمكيرى شـده و E ميانخين تابش تخمين و اندازهگيرى شده است.

${ }^{1}$ Root Mean Square Eror 


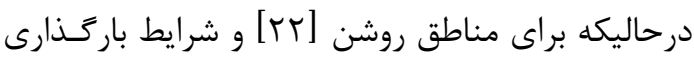

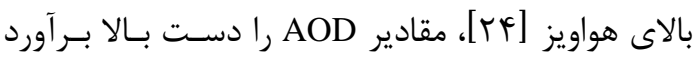

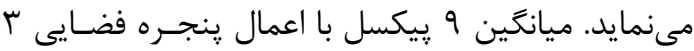

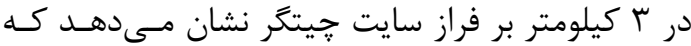

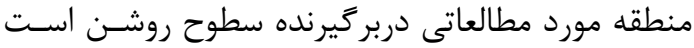

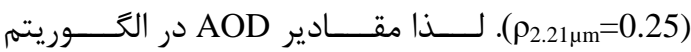
محصولات ماديس، بالاتر از حد واقعى برآورد مى

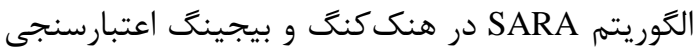

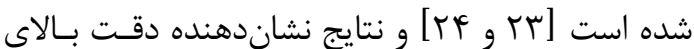

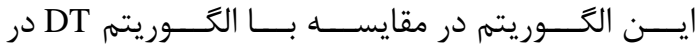

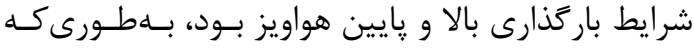
RMSE

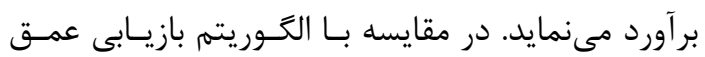

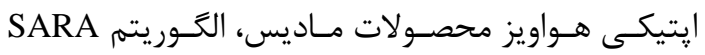

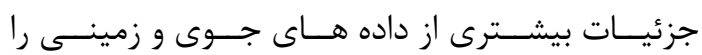

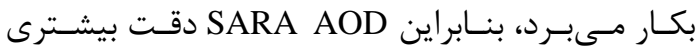
نسبت به اين محصولات دارد. بازتابندىى سطح و بـالاى جو ماديس با قدرتتفكيكمكانى ا كيلـومتر بـههمــــاه

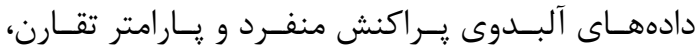

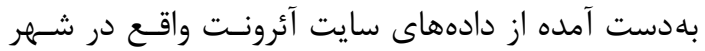
زنجان، از جمله دادهاى مورد نياز در الكَوريتم SARA

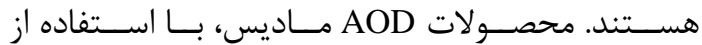

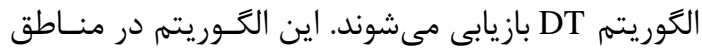
با يوشش كياهى متراكم از دقت مناسبى برخوردار است است إن

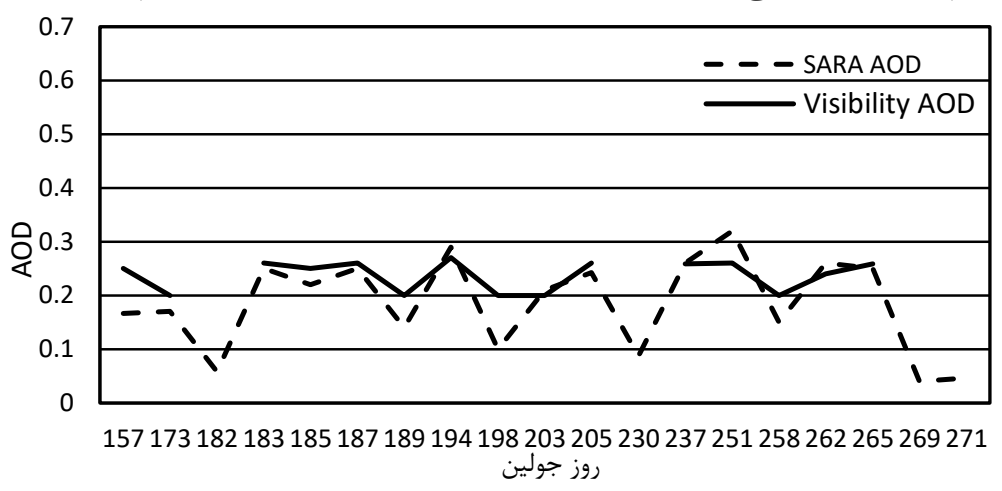

(الف)

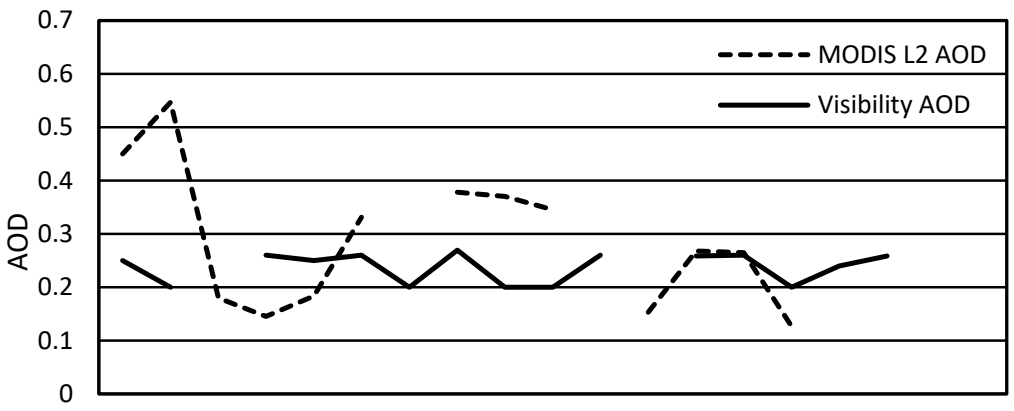

157173182183185187189194198203205230237251258262265269271 روز جولين

(ب) 


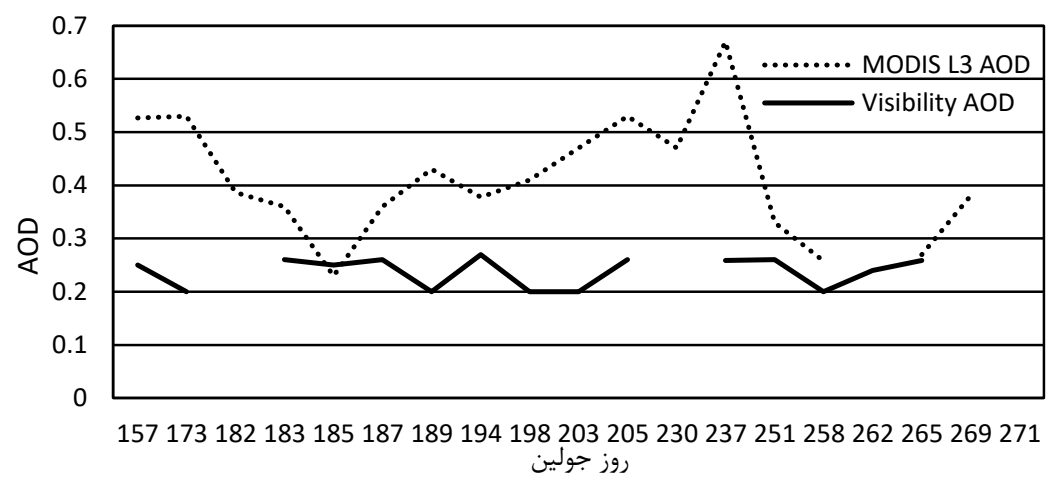

(ج)

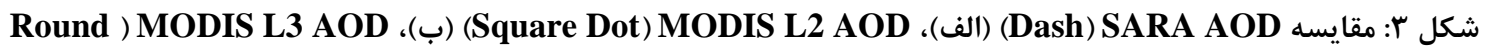

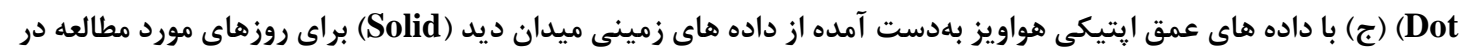

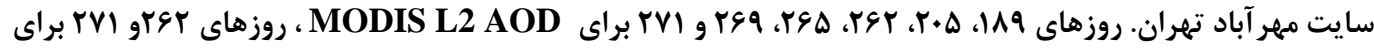

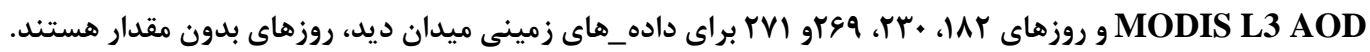

مقايسه با مناطق اطر اف نشان مىدهد (شـكل F ا-الـف).

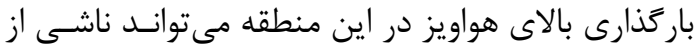

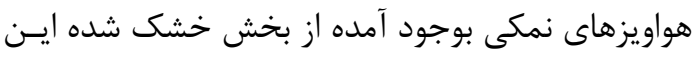
درياجه و همجنين گرد و خاك هاى دشت كوير باشـد.

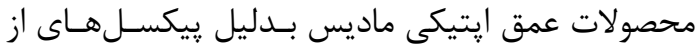

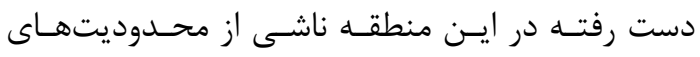

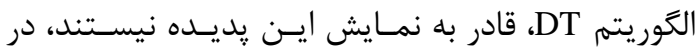

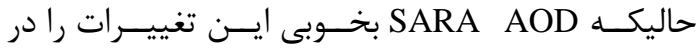
بخشهاى مختلف درياجه نمايش مىدهد.

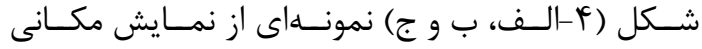

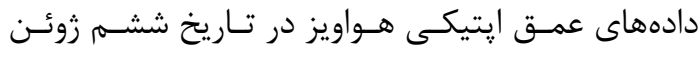

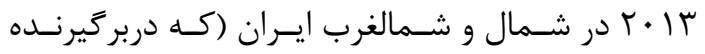
سايت جيتخر تهران و IASBS زنجان و منـاطق مجـاور

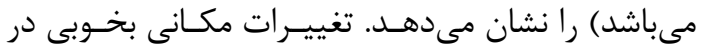
SARA AOD

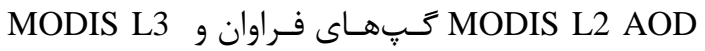
علاوه بر وجود گٍ، قدرت تفكيك مكانى پـايينى AOD

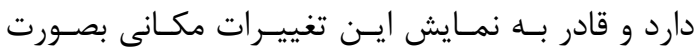

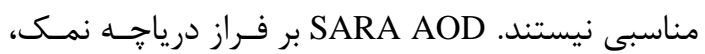

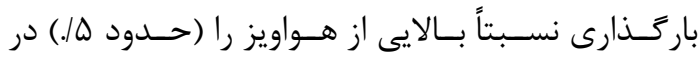




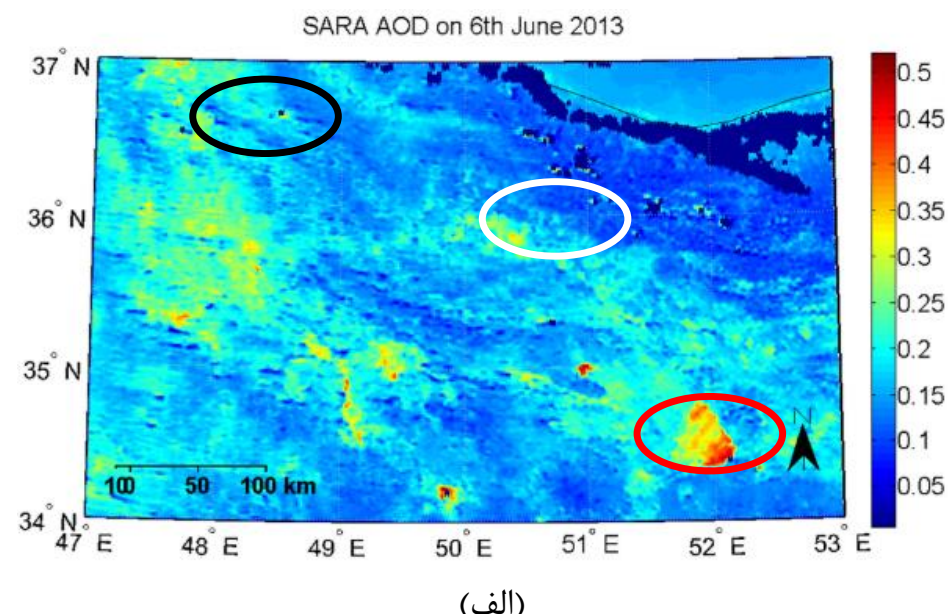

(الف)

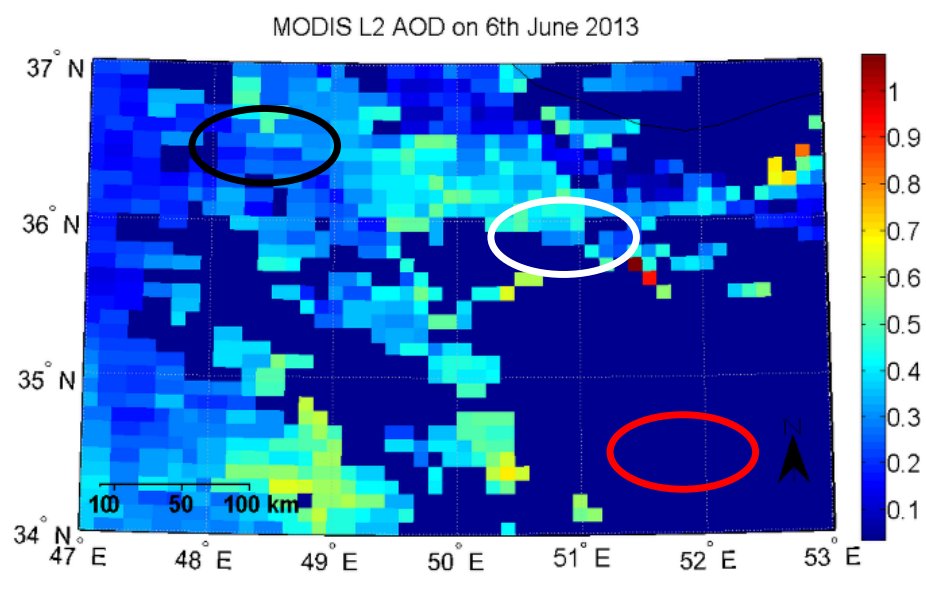

(ب)

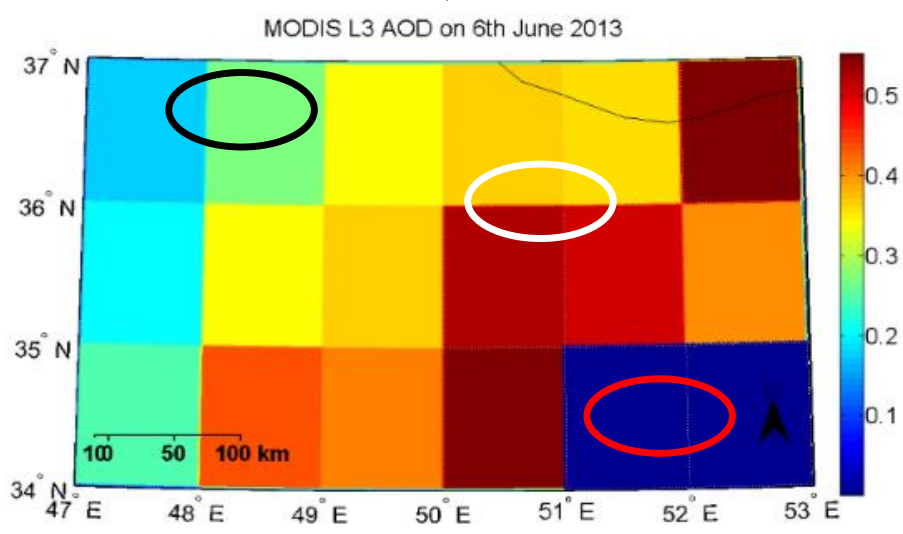

(ج)

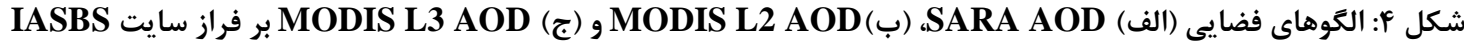
واقع در شهر زنجان (بيضى سياه)، سايت جيتگر مستقر در شهر تهران (بيضى سفيد) و درياجه نمك (بيضى قرمز ) در تاريخ

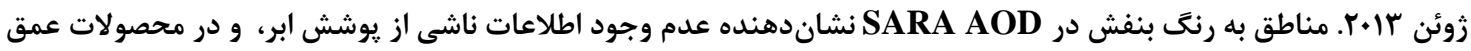

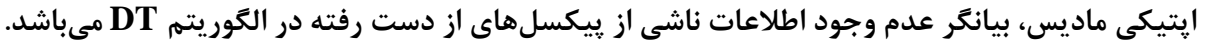


خطــاى بوجــود آمــده از محصــول ســـح دو مــاديس

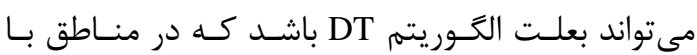
سطوح روشن مقدار AOD را دست بالا برآورد مىنمايد. بين تابش و AOD ارتباط معكوسى وجود دارد، بنابراين

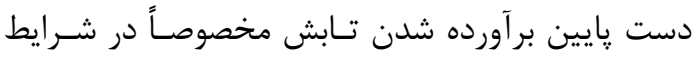

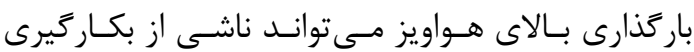
محصول سطح دو ماديس باشد. خطاى بوجـود آمــده از محصول سطح سه ماديس نيز كه منجر به دست يـايين بر آورد شدن قابل ملاحظه تابش در همه شرايط هـواويز شده است مى تواند به دو علت باشد، ( ) قدرت تفكيــ ماند

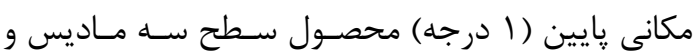

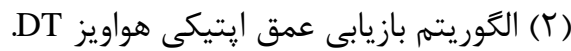

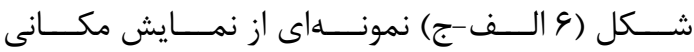
MODIS L2، SARA AOD تابش موج كوتاه براسـاس نماس

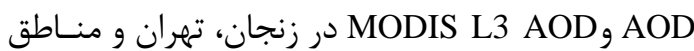

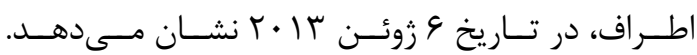

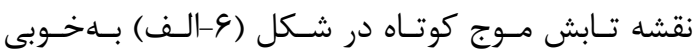

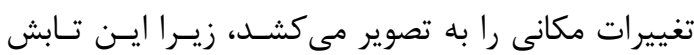
بر اساس SARA AOD و با قدرت تفكيك مكـانى يـك

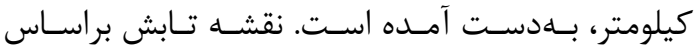

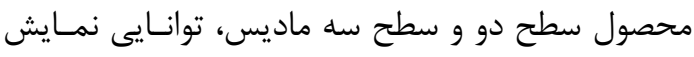

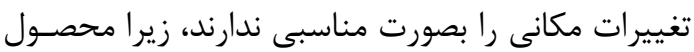

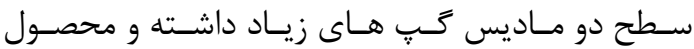
سطح سـه، قـدرت تفكيـك مكـانى زـايين دارد. تـابش

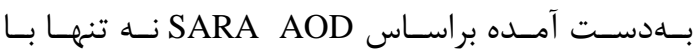
مشاهدات زمينى در توافق خوبى است، نمـايش بهتـرى نيز از تغييرات مكانى را نشان مى دهدي.

\section{ץ-Y - اعتبارسنجى تابشهـــ بــر آورد شــده در سايت جيتگر} شكل (ه الف- ب و ج) و جدول (V)، اعتبارسنجى تابش

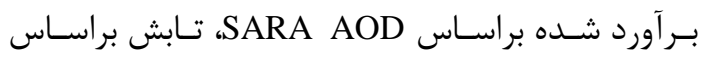
MODIS L3 و تسابش براسـاس MODIS L2 AOD AOD، با اندازمكيريهاى بيرانومتر واقع در سايت جيتخر

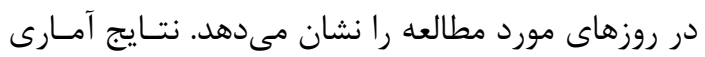

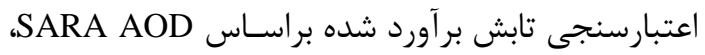

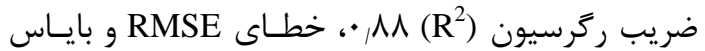

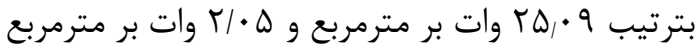

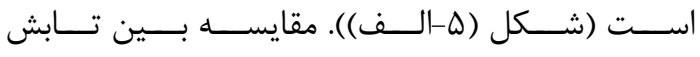

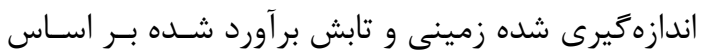

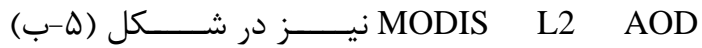

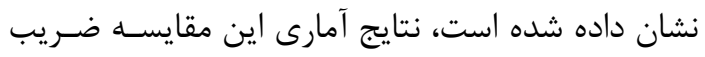

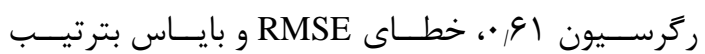

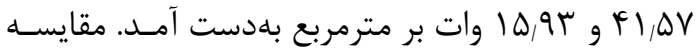
بين تابش اندازهيرى شده زمينى و تابش برآورد شـدهد

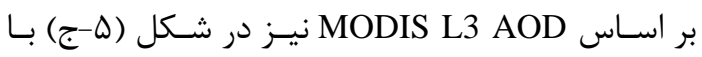
ضريب ركرسيون rAر •، خطاى RMSE و باياس بترتيب تار

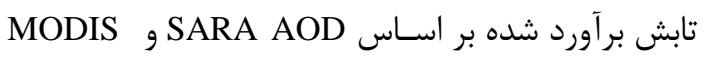

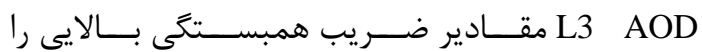

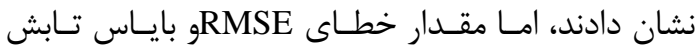

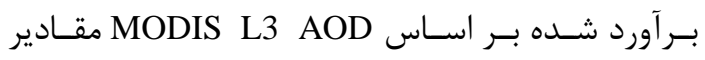

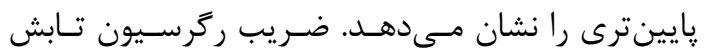

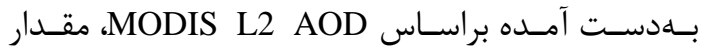

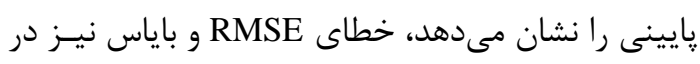

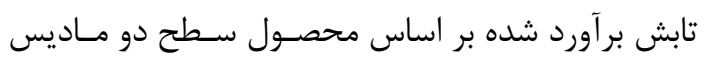

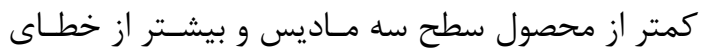
بهدست آمده در تابش براساس SARA AOD مكىباشـــ 

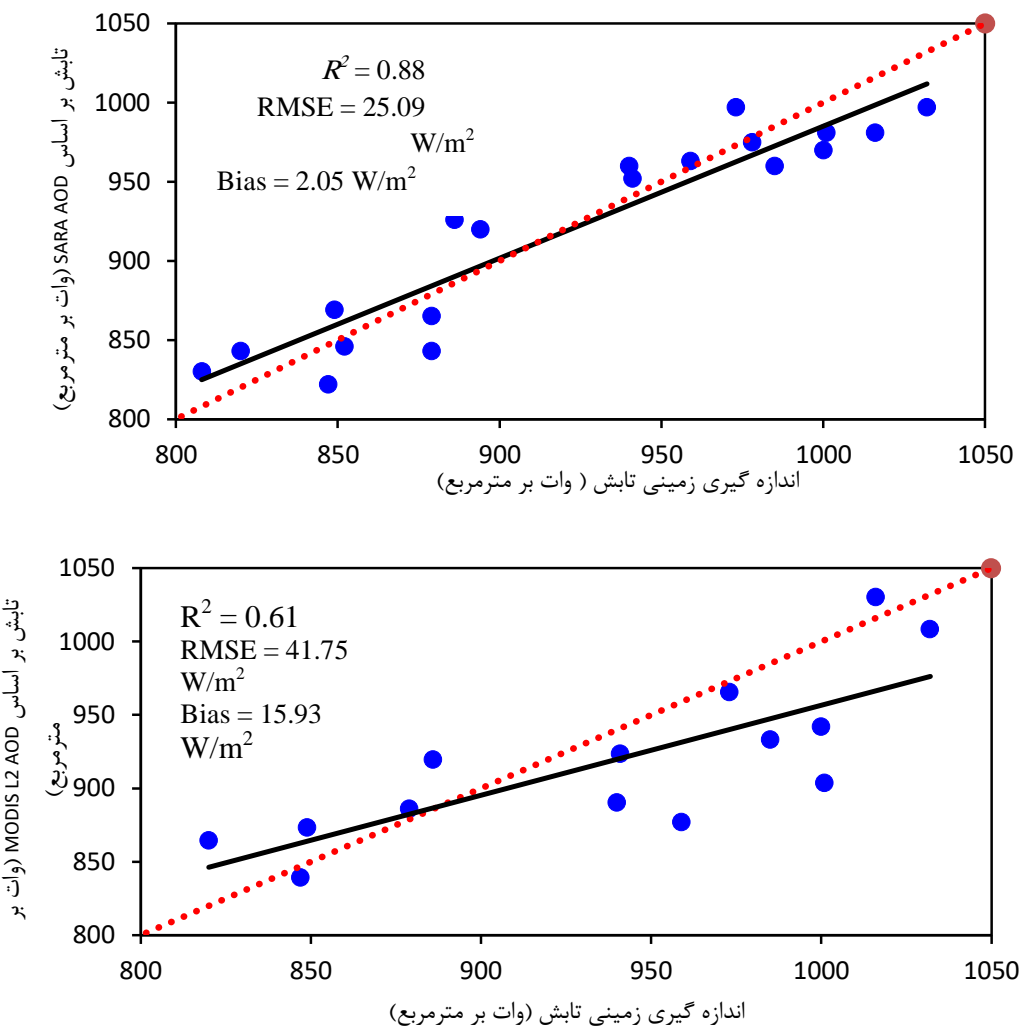

ج

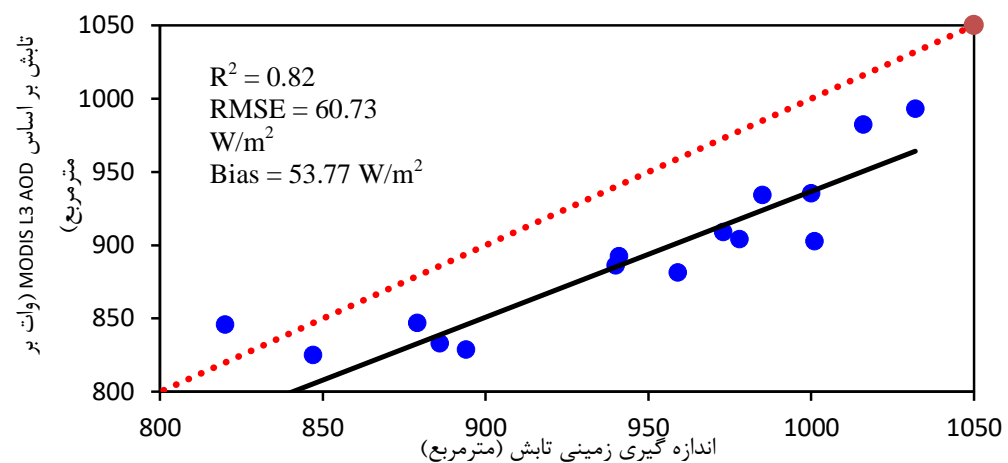

شكل ه: اعتبارسنجى تابشهاى بر آورد شده براساس دادههاى مختلف عمق ايتيكى هواويز (الف) SARA AOD

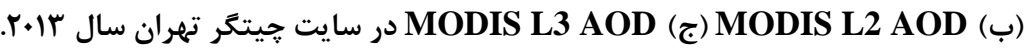
جدول V: اطلاعات آمارى ارزيابى تابشهاى تخمين شده براساس دادههاى مختلف عمق إيتيكى با تابشهاى اندازهكيرى شده

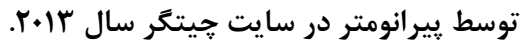

\begin{tabular}{|c|c|c|c|}
\hline (وات بر مترمربع) & $\begin{array}{c}\text { RMSE } \\
\text { (وات بر مترمربع) }\end{array}$ & $\mathbf{R}^{2}$ & تابش موجكو تاه \\
\hline$r / \cdot \Delta$ & $r \Delta / \cdot q$ & $\cdot / \Lambda \Lambda$ & SARA AOD \\
\hline $10 / 91$ & $F I / V \Delta$ & $\cdot|9|$ & MODIS L2 AOD \\
\hline$\Delta r / V V$ & $\varepsilon \cdot / V T$ & . IAT & MODIS L3 AOD \\
\hline
\end{tabular}




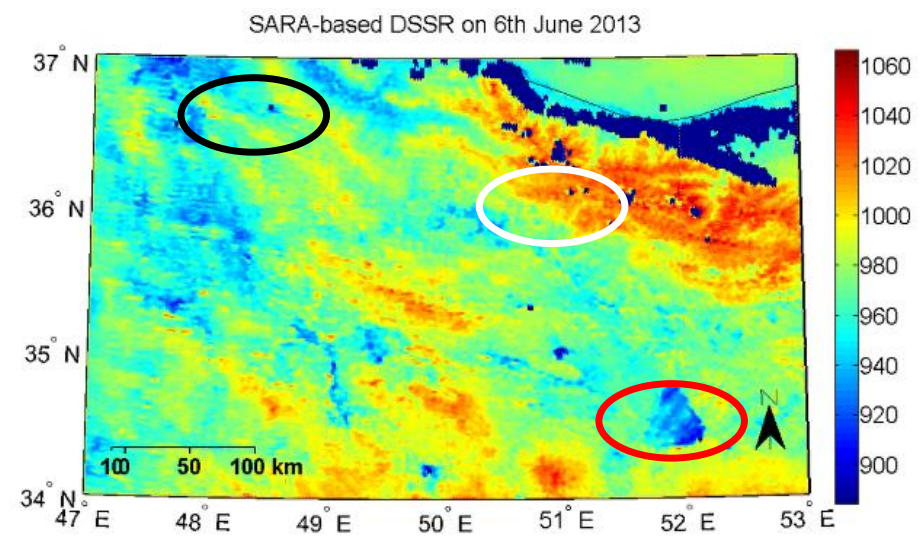

(الف)

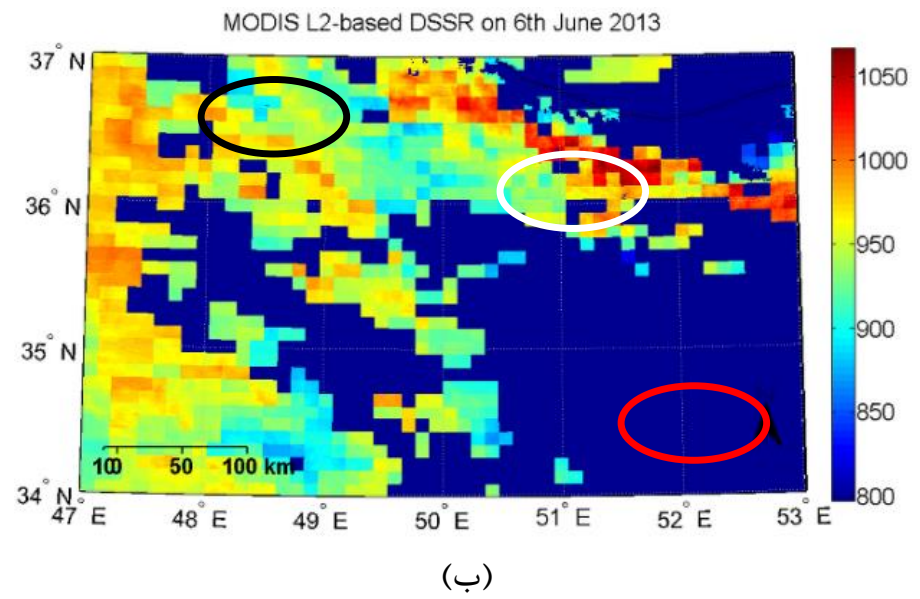

MODIS L3-based DSSR on 6th June 2013

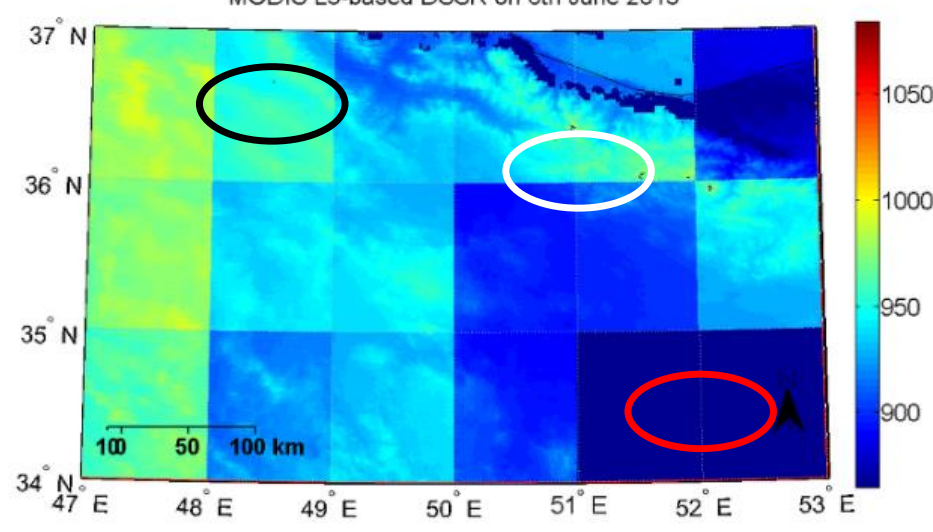

(ج)

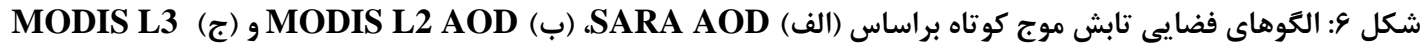

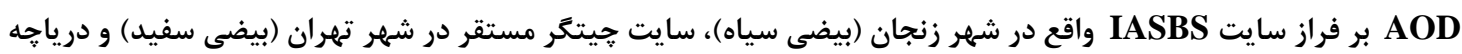

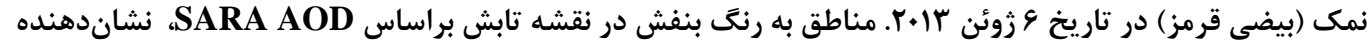

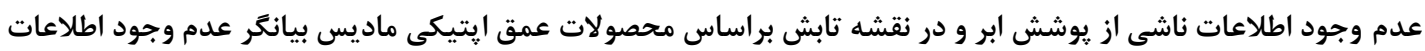

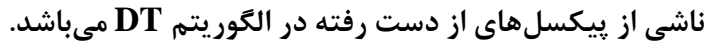


براى محاسبه AOD عنوان كرد. البته ضريب ركرسـيون بهدست آمده از اين روش در مقايسه با تحقيقات قبلى

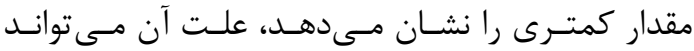

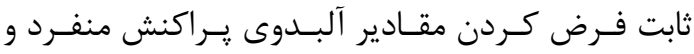
فاكتور تقارن در منطقه مورد مطالعه (زنجان تا تهـران)

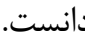

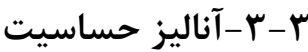

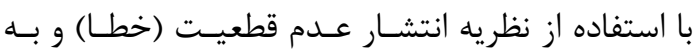
كمك مدل يانگ آناليز حساسيت بصورت زير انجام شد. $\Delta I=\left|\frac{\partial I}{\partial \tau}\right| \Delta \tau$

رابطه (Tr)

كه I تابش موج كوتاه فرودى، 4 كدم قطعيت AOD و

$\Delta I$

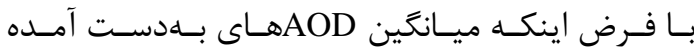
بر اساس دادههاى ميدان ديد، זٓ⿱ • باشد (رجوع شـود

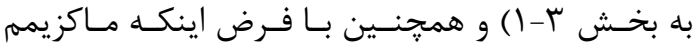

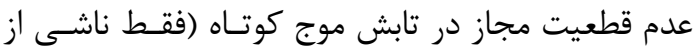

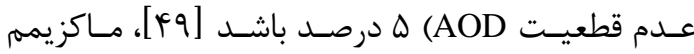

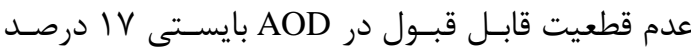
باشد (يعنى مقدار وץ+• •• در واحد AOD). عدم قطعيت

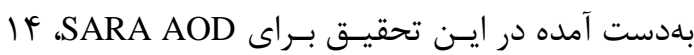

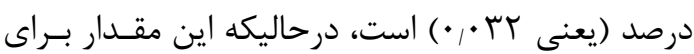

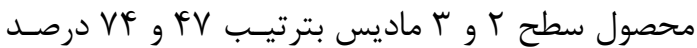

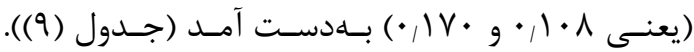

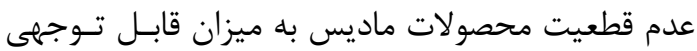

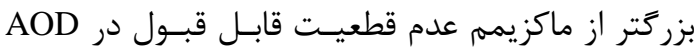
مىباشد و عدم قطعيت SARA AOD كمتر از ماكزيمهم

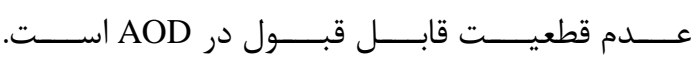
بنابراين اين نتايج نيز دقت بـالاى SARA AOD بـاى فراى

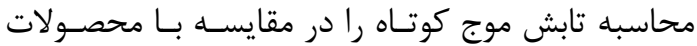
سطح r و r ماديس نشان مى دهد. لازم بذكر است كـه به بهدست آمده از دادههاى ميدان ديد، شايد معيار مناسبى براى اعتبارسنجى AOD هاى بكار رفته در اين تحقيق نباشد و بهتر است از دادههاى دقيقتـر آئرونست
نتايج آمارى تابش برآورد شده براسـاس SARA AOD

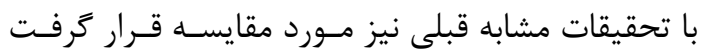

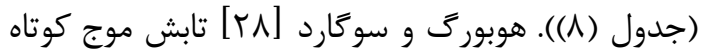
را براساس محصول سـطح دو مـاديس و بــا اسـتفاده از

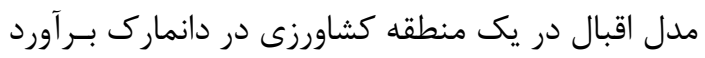

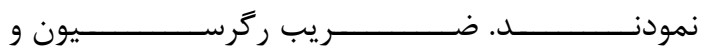

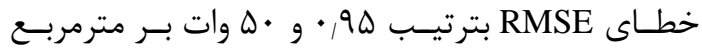

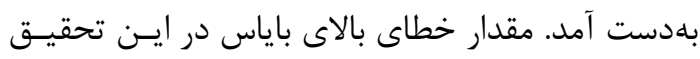

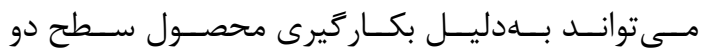

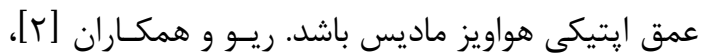

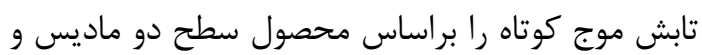

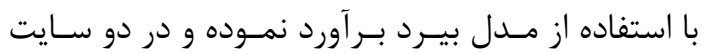

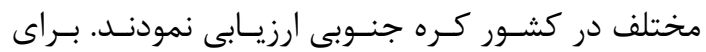

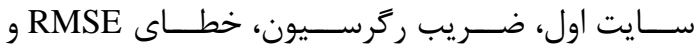

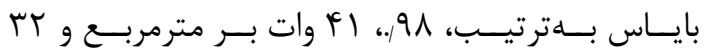

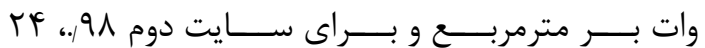

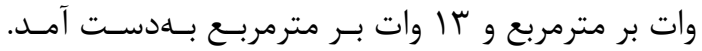

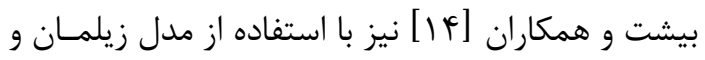

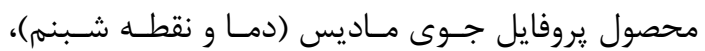

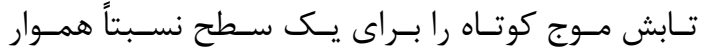

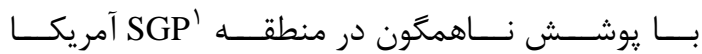

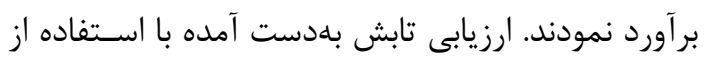

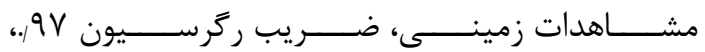

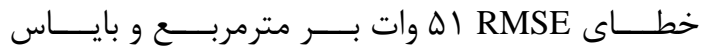

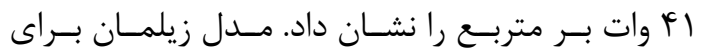

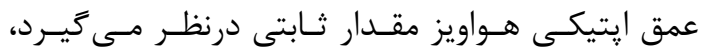

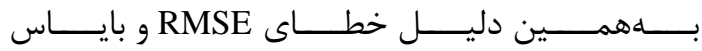
مقدار بزركى دارند. در مقايسه با تابشهاى برآورد شـده

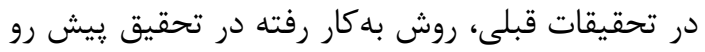

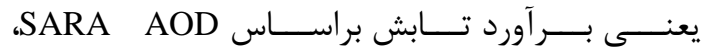

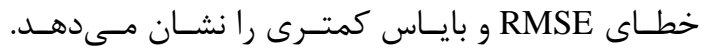

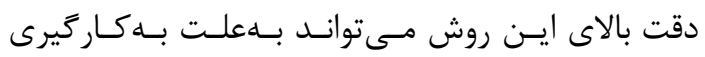
مستقيم دادههاى بازتابندگى سطح و بالاى جو مـاديس

\footnotetext{
${ }^{1}$ Southern Great Plains
} 
بدين منظور استفاده گردد. تنها داده موجـود در منطقـهـ مورد مطالعه، دادههاى ميدان ديد بودند. جدول ^: اطلاعات آمارى تابش بر آورد بر اساس روش يِيشنهادى، در مقايسه با تحقيقات قبلى مشابه

\begin{tabular}{|c|c|c|c|}
\hline 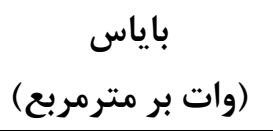 & $\begin{array}{c}\text { RMSE } \\
\text { (وات بر مترمربع) }\end{array}$ & $\mathbf{R}^{2}$ & روش بكار رفته در \\
\hline$r / \cdot \Delta$ & $r \Delta / \cdot q$ & $\cdot \mid \Lambda \Lambda$ & تحقيق ييش رو \\
\hline rr-Ir & $F \mid-F^{\prime}$ & $\cdot 191-\cdot 191$ & ريو و همكاران \\
\hline$p_{1}$ & $\Delta 1$ & $.19 \mathrm{~V}$ & بيشت و همكاران \\
\hline- & $i \wedge$ & .190 & هوبورى و سو گارد \\
\hline
\end{tabular}

جدول 9: آناليز حساسيت محاسبه تابش موج كو تاه بر اساس دادههاى مختلف AOD

\begin{tabular}{|c|c|c|c|}
\hline عدم قطعيت در واحد AOD & عدم قطعيت (.) & ميانگين AOD & AOD \\
\hline • & If & $\cdot 11$ & SARA AOD \\
\hline$\cdot 1 \cdot 1$ & FV & $\cdot$, rᄉ & MODIS L2 AOD \\
\hline$\cdot 1 \mathrm{~V} \cdot$ & $V F$ & $\cdot|f|$ & MODIS L3 AOD \\
\hline
\end{tabular}

مترمربع و برآورد تـابش براسـاس محصـول سـطح ســه

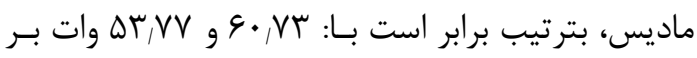

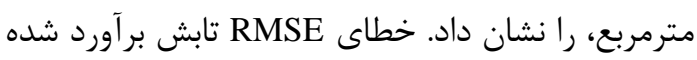

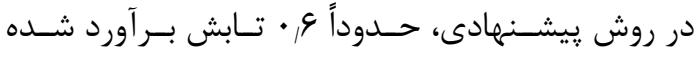

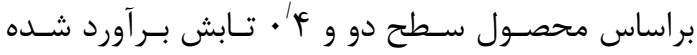
براساس محصول سطح سه ماديس است. خطاى بايساس

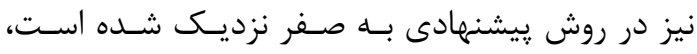
درحالى كه در روشهــاى براسـاس محصـولات مـاديس، اين خطا مقدار بالايى دارد.

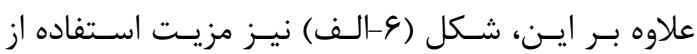
نسبت به محصولات عمق ايتيكى هواويز SARA AOD

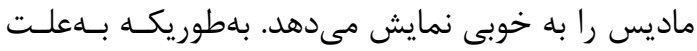

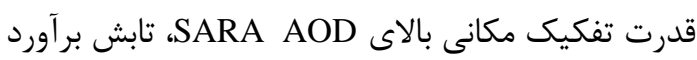

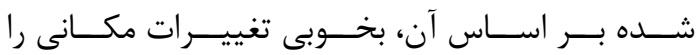
نمـايش مـى دهــد، درحاليكــهـ ايسن تغييـرات مكـانى در

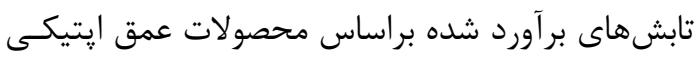
هواويز بهصورت مناسـبى ديـده نمسىشـود. جنانجــه در

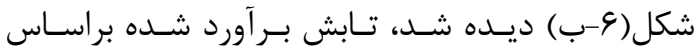

F در اين تحقيـق يسـ از ارائسه روش ييشــــهادى بــرآورد تـابش براسـاس SARA AOD، تـابش مـوج كوتــاه در

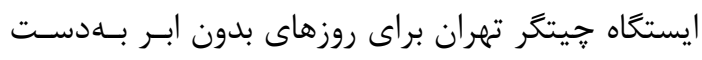

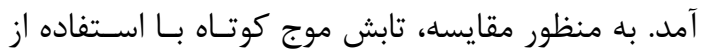

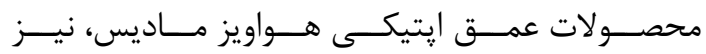

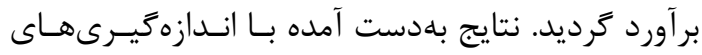
زمينى اعتبارسنجى شدند. نتايج ارائه شده در شكل (ه) بردائ

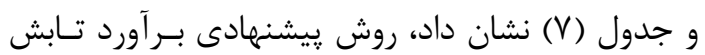

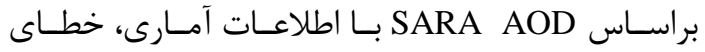
RMSE و باياس بترتيب برابـر است بـا: 9 ••/ه و ه • •

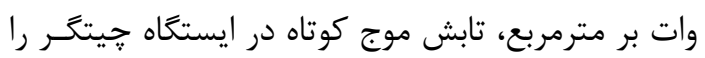
برآورد نمود. اين روش در مقايسه بـا روشهــاى بـرآورد تابش براساس محصولات عمـق ايتيكى مــاديس مانــد MODIS L3 AODو MODIS L2 AOD بههمراه داشـت. بطوريكــه نتـايج آمـارى بـــــآورد تـابش براساس محصول سـطح دو مـاديس، خطـاى RMSE و

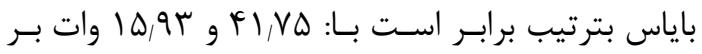


توزيع مكانى مناسبى از شبكه آئرونت در كشور است. با فرض در دسترس بودن קنين شبكهاى در آينده، روش

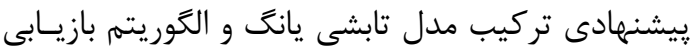

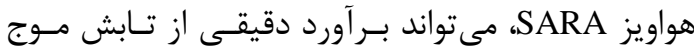

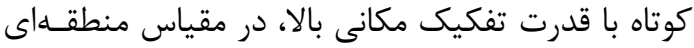

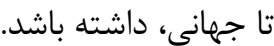

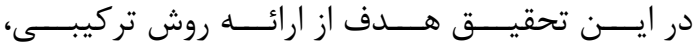
تخمين دقيق تابش موجكوتاه با قدرت تفكيكمكانى بالا (1 كيلومتر) با استفاده از دادههاى مـاديس، در مقيـاس

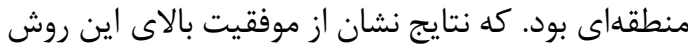

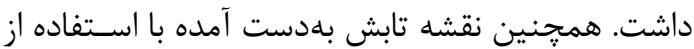

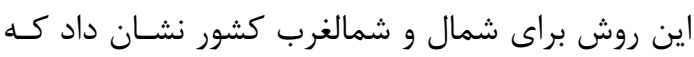

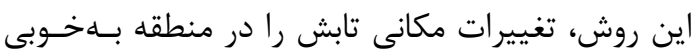

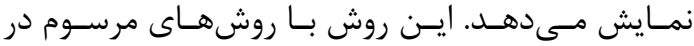
مطالعات ييشين نيز مورد مقايسه قرار كرفت كـهـ نتـايج

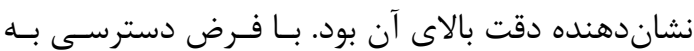

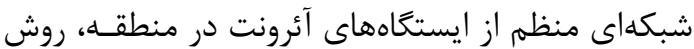

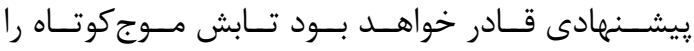
با قـدرت تفكيـكمكـانى ا كيلـومتر بـراى كاربردهــاى

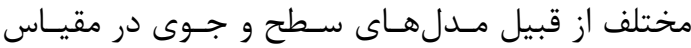
منطقهاى تا جهانى بر آورد نمايد.

[1] M. Castelli, R. Stöckli, D. Zardi, A. Tetzlaff, J. E. Wagner, G. Belluardo, et al., "The HelioMont method for assessing solar irradiance over complex terrain: Validation and improvements," Remote Sensing of Environment, vol. 152, pp. 603-613, 2014.

[2] Y. Ryu, S. Kang, S.-K. Moon, and J. Kim, "Evaluation of land surface radiation balance derived from moderate resolution imaging spectroradiometer (MODIS) over complex terrain and heterogeneous landscape on clear sky days," Agricultural and Forest Meteorology, vol. 148, pp. 1538-1552, 2008.

[3] S. Liang, Advanced Remote Sensing. Boston: Academic Press, 2012.

[4] L. Chen, G. Yan, T. Wang, H. Ren, J.
محصول سطح دو ماديس قدرت تفكيـك مناسـبى دارد

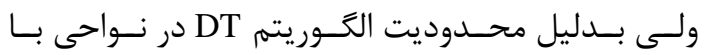
سطوح روشن و همجِنين در مناطق با باركـذارى بـالاى

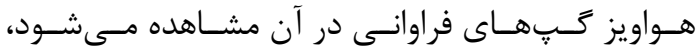
تابش برآورد شده براساس محصول سطح سـه مـاديس

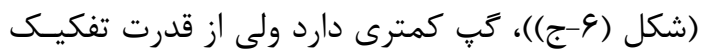
مناسـبـى بـــراى نمــايش تغييــرات تــابش در منطقــه،

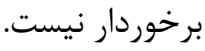

SARA مقايسه روش ييشنهادى بر آورد تابش براسـاس

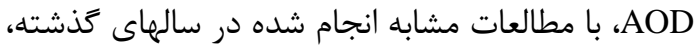
نشــان داد كـــه ايــن روش از دقــت بمراتــب بــالاترى

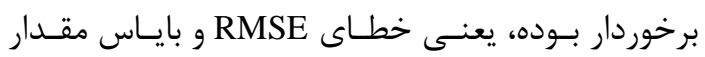

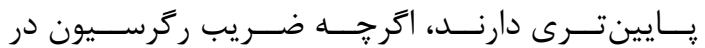
روش يِيشنهادى، درمقايسه با مطالعـات ييشـين مقـدار

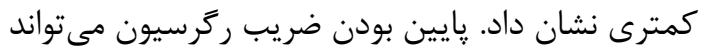
بعلت ثابت فرض كردن مقادير آلبدوى يراكنش منفرد ورئ

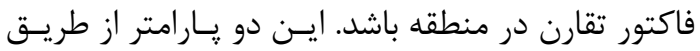

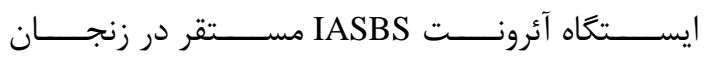

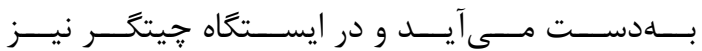
مورد استفاده قرار مى ئيرد. لذا براى محاسـبه تـابش بـــا روش پييشنهادى در مقياس منطقهاى و جهانى، نياز بــه

\section{مراجع}

Calbó, J. Zhao, et al., "Estimation of surface shortwave radiation components under all sky conditions: Modeling and sensitivity analysis," Remote Sensing of Environment, vol. 123, pp. 457-469, 2012.

[5] C. A. Gueymard, "Temporal variability in direct and global irradiance at various time scales as affected by aerosols," Solar Resources, vol. 86, pp. 3544-3553, 2012.

[6] S. Liang, Quantitative Remote Sensing of Land Surfaces. Hoboken, NJ: John Wiley \& Sons, Inc., 2004.

[7] R. T. Pinker and I. Laszlo, "Modeling Surface Solar Irradiance for Satellite Applications on a Global Scale," Journal of Applied Meteorology, vol. 31, pp. 194-211, 1992. 
[8] Z. Li, H. G. Leighton, K. Masuda, and T. Takashima, "Estimation of SW Flux Absorbed at the Surface from TOA Reflected Flux," Journal of Climate, vol. 6, pp. 317-330, 1993.

[9] G. L. Stephens, A. Slingo, M. J. Webb, P. J. Minnett, P. H. Daum, L. Kleinman, et al., "Observations of the Earth's Radiation Budget in relation to atmospheric hydrology: 4. Atmospheric column radiative cooling over the world's oceans," Journal of Geophysical Research: Atmospheres, vol. 99, pp. 18585-18604, 1994.

[10] Y. C. Zhang, W. B. Rossow, and A. A. Lacis, "Calculation of surface and top of atmosphere radiative fluxes from physical quantities based on ISCCP data sets: 1 . Method and sensitivity to input data uncertainties," Journal of Geophysical Research: Atmospheres, vol. 100, pp. 1149$1165,1995$.

[11] S. K. Gupta, N. A. Ritchey, A. C. Wilber, C. H. Whitlock, G. G. Gibson, and P. W. Stackhouse, "A Climatology of Surface Radiation Budget Derived from Satellite Data," Journal of Climate, vol. 12, pp. 2691-2710, 1999

[12] R. W. Mueller, K. F. Dagestad, P. Ineichen, M. Schroedter-Homscheidt, S. Cros, D. Dumortier, et al., "Rethinking satellitebased solar irradiance modelling: The SOLIS clear-sky module," Remote Sensing of Environment, vol. 91, pp. 160-174, 2004.

[13]C. Rigollier, M. Lefèvre, and L. Wald, "The method Heliosat-2 for deriving shortwave solar radiation from satellite images," Solar Energy, vol. 77, pp. 159-169, 2004.

[14] . Bisht, V. Venturini, S. Islam, and L. Jiang, "Estimation of the net radiation using MODIS (Moderate Resolution Imaging Spectroradiometer) data for clear sky days," Remote Sensing of Environment, vol. 97, pp. 52-67, 2005.

[15]H.-Y. Kim and S. Liang, "Development of a hybrid method for estimating land surface shortwave net radiation from MODIS data," Remote Sensing of Environment, vol. 114, pp. 2393-2402, 2010.

[16]MODIS (2016, Web Page). Modis Moderate Resolution Imaging Spectroradiometer. Available: http://modis.gsfc.nasa.gov/

[17] G. Huang, S. Liu, and S. Liang, "Estimation of net surface shortwave radiation from MODIS data," International Journal of Remote Sensing, vol. 33, pp. 804-825, 2012.

[18] M. Suri, J. Remund, T. Cebecauer, C. Hoyer-Click, D. Dumortier, T. Huld, et al., "Comparison of Direct Normal Irradiation Maps for Europe," in Solar Paces, ed. Berlin, Germany: In: Proc. SolarPACES Conf, 2009.

[19]C. A. Gueymard, "Uncertainties in Modeled Direct Irradiance Around the Sahara as Affected by Aerosols: Are Current Datasets of Bankable Quality?," Journal of Solar Energy Engineering, vol. 133, pp. 031024-031024, 2011.

[20] R. C. Levy, L. A. Remer, S. Mattoo, E. F. Vermote, and Y. J. Kaufman, "Secondgeneration operational algorithm: Retrieval of aerosol properties over land from inversion of Moderate Resolution Imaging Spectroradiometer spectral reflectance," Journal of Geophysical Research: Atmospheres, vol. 112, p. D13211, 2007.

[21] N. C. Hsu, T. Si-Chee, M. D. King, and J. R. Herman, "Aerosol properties over bright-reflecting source regions," Geoscience and Remote Sensing, IEEE Transactions on, vol. 42, pp. 557-569, 2004.

[22] R. C. Levy, L. A. Remer, R. G. Kleidman, S. Mattoo, C. Ichoku, R. Kahn, et al., "Global evaluation of the Collection 5 MODIS dark-target aerosol products over land," Atmospheric Chemistry and Physics, vol. 10, pp. 10399-10420, 2010.

[23] M. Bilal, J. E. Nichol, M. P. Bleiweiss, and D. Dubois, "A Simplified high resolution 
MODIS Aerosol Retrieval Algorithm (SARA) for use over mixed surfaces," Remote Sensing of Environment, vol. 136, pp. 135-145, 2013.

[24] M. Bilal, J. E. Nichol, and P. W. Chan, "Validation and accuracy assessment of a Simplified Aerosol Retrieval Algorithm (SARA) over Beijing under low and high aerosol loadings and dust storms," Remote Sensing of Environment, vol. 153, pp. 5060, 2014.

[25]P. Hubanks, M. King, S. Platnick, and R. Pincus, "MODIS atmosphere L3 gridded product algorithm theoretical basis document Collection 005 Version 1.1," 2008.

[26] L. Chengcai, A. K. H. Lau, M. Jietai, and D. A. Chu, "Retrieval, validation, and application of the $1-\mathrm{km}$ aerosol optical depth from MODIS measurements over Hong Kong," IEEE Transactions on Geoscience and Remote Sensing, vol. 43, pp. 2650-2658, 2005.

[27]M. S. Wong, J. E. Nichol, and K. H. Lee, "An operational MODIS aerosol retrieval algorithm at high spatial resolution, and its application over a complex urban region," Atmospheric Research, vol. 99, pp. 579589, 2011.

[28]R. M. Houborg and H. Soegaard, "Regional simulation of ecosystem $\mathrm{CO} 2$ and water vapor exchange for agricultural land using NOAA AVHRR and Terra MODIS satellite data. Application to Zealand, Denmark," Remote Sensing of Environment, vol. 93, pp. 150-167, 2004.

[29] R. E. Bird and R. L. Hulstrom, "Review, Evaluation, and Improvement of Direct Irradiance Models," Journal of Solar Energy Engineering, vol. 103, pp. 182-192, 1981.

[30]M. Iqbal, "Total (Broadband) Radiation under Cloudless Skies," in An Introduction to Solar Radiation, M. Iqbal, Ed., ed Toronto: Academic Press, 1983, pp. 169213.
[31] K. Yang, G. W. Huang, and N. Tamai, "A hybrid model for estimating global solar radiation," Solar Energy, vol. 70, pp. 13-22, 2001 .

[32]B. Leckner, "The spectral distribution of solar radiation at the earth's surfaceelements of a model," Solar Energy, vol. 20, pp. 143-150, 1978.

[33]C. A. Gueymard, "Direct solar transmittance and irradiance predictions with broadband models. Part I: detailed theoretical performance assessment," Solar Energy, vol. 74, pp. 355-379, 2003.

[34]C. A. Gueymard, "Direct solar transmittance and irradiance predictions with broadband models. Part II: validation with high-quality measurements," Solar Energy, vol. 74, pp. 381-395, 2003.

[35] M. Paulescu and Z. Schlett, "Performance assessment of global solar irradiation models under Romanian climate," Renewable Energy, vol. 29, pp. 767-777, 2004.

[36] M. Paulescu and Z. Schlett, "A simplified but accurate spectral solar irradiance model," Theoretical and Applied Climatology, vol. 75, pp. 203-212, 2003.

[37] M. A. Madkour, M. El-Metwally, and A. B. Hamed, "Comparative study on different models for estimation of direct normal irradiance (DNI) over Egypt atmosphere," Renewable Energy, vol. 31, pp. 361-382, 2006.

[38] IRIMO (2016, Web Page). I. R. of Iran Meteorological Office. Available: http://www.irimo.ir/

[39] B. N. Holben, T. F. Eck, I. Slutsker, D. Tanré, J. P. Buis, A. Setzer, et al., "AERONET-A Federated Instrument Network and Data Archive for Aerosol Characterization," Remote Sensing of Environment, vol. 66, pp. 1-16, 1998.

[40] B. N. Holben, D. Tanré, A. Smirnov, T. F. Eck, I. Slutsker, N. Abuhassan, et al., "An emerging ground-based aerosol climatology: Aerosol optical depth from 
AERONET," Journal of Geophysical Research: Atmospheres, vol. 106, pp. 12067-12097, 2001.

[41]E. F. Vermote, S. Vibert, H. Kilcoyne, D. Hoyt, and T. Zhao, "Suspended Matter. Visible/Infrared Imager/Radiometer Suite algorithm theroretical basis document. SBRS Document\# Y2390, Raytheon Systems Company," Information Technology and Scientific Services, Maryland, 2002.

[42] NASA (2016, Web Page). Modis Level 1, Atmosphere and Land data products Available: http://ladsweb.nascom.nasa.gov.

[43] O. Lado-Bordowsky and I. Naour, "Optical paths involved in determining the scattering angle for the scattering algorithm developed in LOWTRAN7," International Journal of Infrared and Millimeter Waves, vol. 18, pp. 1689-1696, 1997.

[44]H. Rahman, B. Pinty, and M. M. Verstraete, "Coupled surface-atmosphere reflectance (CSAR) model: 2. Semiempirical surface model usable with NOAA advanced very high resolution radiometer data," Journal of Geophysical Research: Atmospheres, vol. 98, pp. 2079120801, 1993.

[45]R. C. Levy, L. A. Remer, and O. Dubovik, "Global aerosol optical properties and application to Moderate Resolution
Imaging Spectroradiometer aerosol retrieval over land," Journal of Geophysical Research: Atmospheres, vol. 112, p. D13210, 2007.

[46] D. Tanre, M. Herman, P. Y. Deschamps, and A. d. Leffe, "Atmospheric modeling for space measurements of ground reflectances, including bidirectional properties," Appl.Opt., vol. 18, pp. 3587-3594, 1979.

[47] C. Kelley, Iterative Methods for Linear and Nonlinear Equations: Society for Industrial and Applied Mathematics, 1995.

[48] C. Ichoku, R. Levy, Y. J. Kaufman, L. A. Remer, R.-R. Li, V. J. Martins, et al., "Analysis of the performance characteristics of the five-channel Microtops II Sun photometer for measuring aerosol optical thickness and precipitable water vapor," Journal of Geophysical Research: Atmospheres, vol. 107, pp. AAC 5-1-AAC 5-17, 2002.

[49] J. A. Ruiz-Arias, J. Dudhia, C. A. Gueymard, and D. Pozo-Vazquez, "Assessment of the Level-3 MODIS daily aerosol optical depth in the context of surface solar radiation and numerical weather modeling," Atmospheric Chemistry and Physics, vol. 13, pp. 675692, 2013 


\title{
Development and evaluation of Downward Surface Shortwave Radiation based on SARA AOD using MODIS data under cloud-free conditions
}

Javadnia, E. *1 ${ }^{1}$ Abkar, A. ${ }^{2}$

1- PhD student of remote sensing in Department of Photogrammetry and Remote Sensing, Faculty of Geodesy \& Geomatics Engineering, K. N Toosi University of Technology

2- Assisstant professor in Department of Photogrammetry and Remote Sensing, Faculty of Geodesy \& Geomatics Engineering, K. N. Toosi University of Technology

\begin{abstract}
The atmospheric Aerosol Optical Depth (AOD) is one of the major uncertainties in retrieving Downward Surface Shortwave Radiation (DSSR). In the current study, Yang's model, which determines the effect of each component of atmosphere separately, was used to estimate DSSR under cloud-free conditions. Recent studies have used MODIS AOD data to calculate DSSR, while in this article the retrieved AOD from the Simplified Aerosol Retrieval Algorithm (SARA) was used to estimate DSSR over the Chitgar site in Tehran, Iran. For comparison purpose, MODIS AOD products were also used to estimate DSSR over the studied region. Estimated DSSR based on SARA AOD, MODIS Level 2 (L2) AOD, and MODIS Level 3 (L3) AOD were evaluated with ground-based measurements of DSSR at the Chitgar site during summer of 2013. Results show R2 = 0.88, RMSE $=25.09 \mathrm{~W} / \mathrm{m} 2$, and Bias $=2.05 \mathrm{~W} / \mathrm{m} 2$ for SARA-based DSSR, and R2 = $0.61, \mathrm{RMSE}=41.75 \mathrm{~W} / \mathrm{m} 2$, and Bias $=15.93 \mathrm{~W} / \mathrm{m} 2$ for MODIS-L2 based DSSR, and R2 $=0.82, \mathrm{RMSE}=60.73 \mathrm{~W} / \mathrm{m} 2$, and Bias $=53.77 \mathrm{~W} / \mathrm{m} 2$ for MODIS L3-based DSSR. The results showed higher accuracy of estimated DSSR based on the SARA AOD than the estimated DSSR based on MODIS products. As RMSE of SARA-based DSSR is 1.6 and 2 times MODIS-L2 based DSSR and MODIS-L3 based DSSR, respectively. In the proposed method, Bias reached close to zero. These results also showed that our modeling scheme of combining Yang's model with the SARA algorithm can be used from the regional to global scale under the assumption of future access to spatially distributed AERONET sites.
\end{abstract}

Key words: Downward surface shortwave radiation, Aerosol optical depth, Moderate Resolution Imaging

Correspondence Address. : Department of Photogrammetry and Remote Sensing, Faculty of Geodesy \& Geomatics Engineering, K. N. Toosi University of Technology, Tehran, Iran

Tel: +98.9125232057

Email: jiavadnia@mail.kntu.ac.ir 